\title{
Tradiciones literarias y tradiciones históricas en Sinuhé, el egipcio de Waltari. Los hititas bajo la óptica de un egipcio
}

\author{
Literary traditions versus historical traditions in Waltari's novel \\ The Egyptian. The Hittites from an Egyptian's lens
}

\author{
Juan Manuel González Salazar*
}

\begin{abstract}
RESUMEN
M. T. Waltari escribió hace más de medio siglo Sinuhé, el egipcio (1945),

novela centrada en las vivencias de un médico dentro del contexto histórico del Egipto faraónico de la Dinastía XVIII.

En este cuadro también se destacó un reino rival, Hatti, y sus poblaciones

hititas. Waltari puso en boca de su protagonista Sinuhé, a veces con una gran libertad literaria, lo que el propio autor en su época pudo llegar a conocer de los hititas y su mundo.
\end{abstract}

PALABRAS CLAVE:

Mika Toimi Waltari, Sinuhé, hititas, egipcios, novela histórica.

\begin{abstract}
Over half a century ago M. T. Waltari wrote The Egyptian (1945), a novel that narrates the vicissitudes of Sinuhe, a physician who lived in the Egypt of the Pharaohs of the 18th Dynasty. Amid this state of affairs the peoples ruled by Hatti gain relevance as a rival kingdom. Thus, Waltari gives an account of the knowledge of the Hittites and their customs he himself might have had access to during his lifetime. Nonetheless, historical facts are often times tainted with great literary freedom.
\end{abstract}

KEY WORDS:

Mika Toimi Waltari, Sinuhe, Hittites, Egyptians, Historical Novel.

Uno de los múltiples campos de conocimiento del profesor Federico Lara Peinado se ha desarrollado durante muchos años en el ámbito de la difusión en España de los estudios sobre la Orientalística antigua ${ }^{1}$. En el páramo en el que se en-

* Laboratorio de Lenguas, Facultad de Filosofía y Letras, Universidad Autónoma de Madrid. E-mail: manuel.gonzalez@uam.es

1 Algunos de sus principales trabajos sobre el tema son: Mitos sumerios y acadios (1984), Himnos 
contraba este amplio campo de investigación referido a este apartado de la rica y destacada Antigüedad oriental aparecieron como un oasis los trabajos de don Federico. Es así como, los que buscábamos abrirnos paso por los intrincados caminos y las procelosas aguas del conocimiento de las arcanas civilizaciones orientales, hemos tenido que acudir en algún momento a beber del pozo de don Federico. Mi contribución no pretende ser más que pequeño elemento constructivo (acaso a modo de adobe) en la edificación del ziggurat que representa este merecido Homenaje con mayúscula. Muchas gracias por tu saber y tu generosidad.

1. Hay novelas que mantienen la frescura de la historia que narran, a pesar del paso de los años. El caso de la literatura histórica, criticada y alabada a partes iguales pero con miles de seguidores que van creciendo cada año, puede proporcionar notables ejemplos. A pesar de que la novela histórica se pueda convertir en una suerte de fotografía apócrifa, velada de la realidad, con sus embellecedoras o idealizadas pinceladas de tiempos pasados, nos deja algunos ejemplos que, no por dejar de ser una narración literaria, proporcionan algunos datos reales o «literales» de hechos o personajes de la Historia.

El caso de Sinuhé, el egipcio (Sinuhe egyptiläinen, 1945) de Mika Toimi Waltari $^{2}$, conservando la nitidez y sencillez narrativa de lo escrito hace más de medio siglo, es muy representativo del acercamiento a la realidad histórica de un período determinado de la Antigüedad oriental bajo el prisma de la literatura. Una de las obras más destacadas dentro de la literatura histórica que supuso una inmersión en un Egipto faraónico que tanto fascinó al autor, y en la que consiguió mezclar de manera brillante aspectos históricos (Egipto es tratado con gran solvencia y claridad) con grandes dosis de fabulación literaria.

M. T. Waltari (Helsinki, 1908-1979) fue un autor muy prolífico en cuanto a los géneros en los que se sumergió y al número de obras publicadas. Tuvo una formación inicial en teología y, posteriormente, en otros estudios humanísticos (filosofía, literatura, estética e historia del arte). Dominaba varias lenguas, y fue un viajero y un conocedor de la Europa que le tocó vivir³. Todo ello y su inquietud por

sumerios (1988), Poema de Gilgamesh (1988), La civilización sumeria (1989), Himnos babilónicos (1990), El arte de Mesopotamia (1990), El Antiguo Egipto (1991), Himno al Templo Eninnu (Trotta, 1996), Código de Hammurabi (1997), Mesopotamia (2000), Leyendas de la Antigua Mesopotamia (2002), Egipto (2003), El Libro de los Muertos (2006), Enuma Elish. Poema babilónico de la creación (2008), entre un largo etc.

2 Obra conocida internacionalmente y traducida a partir de ese momento a multitud de lenguas, además de sufrir una adaptación a la gran pantalla en el año 1954, con el título de The Egyptian, film de la 20th Century Fox, bajo la dirección de Michael Curtiz. A partir de ahora la novela la citaremos por la versión española como WALTARI, Sinuhé, siguiendo la edición de Debolsillo (Random House Mondadori), febrero 2010. En general, para las abreviaturas y siglas empleadas en este artículo, vid. FRIEDRICH, J. y KAMMENHUBER, A., Hethitisches Wörterbuch, Heidelberg 1975 ss.; GÜTERBOCK, H. G. y HOFFNER, H. A. (eds.), The Hittite Dictionary of the Oriental Institute of the University of Chicago, Chicago $1980 \mathrm{ss}$. o la Keilschriftbibliographie de la revista Orientalia.

3 Sobre Waltari existe un estudio biográfico reciente y completo elaborado por el especialista finés Panu Rajala, titulado Unio Mystica. Mika Waltarin elämä ja teokset (Helsinki 2008). En concreto para su formación académica, pp. 93 ss. y 139 ss. Tengo que agradecer efusivamente a la profesora Pirjo Raiskila, de lengua y cultura finesas de la UAM, por el tiempo que me ha dedicado y por el acercamiento 
Tradiciones literarias y tradiciones históricas en Sinuhé, el egipcio de Waltari...

cualquier tipo de conocimiento le hizo manejar unas fuentes históricas de primer orden para abordar muchos de sus trabajos. En nuestro caso, este bagaje le ayudo a perfilar al protagonista Sinuhé y la trama de su libro4: por una parte, no sólo por hacer referencia a un personaje de las fuentes de la Antigüedad faraónica, conocido por la famosa historia de Sinuhé ${ }^{5}$, uno de los más destacados aportes de la literatura egipcia antigua, si bien con aventuras/desventuras y horizontes geográficos y temporales distintos, más limitados que el Sinuhé literario creado por Waltari6; $\mathrm{y}$, por otra parte, por la riqueza de datos que tuvo que utilizar sobre el contexto histórico en el que centró al personaje.

Waltari, tras recibir una educación superior dentro de las Humanidades durante el período de entreguerras y teniendo presente (como refleja el trasfondo de sus propios escritos) un momento de la historia de Europa convulso y complejo, se debió de sumergir en el conocimiento de la Antigüedad Oriental, que ya había dado sus primeros pasos en el ambiente académico con investigaciones arqueológicas, filológicas e históricas cada vez más numerosas ${ }^{7}$.

a esta biografía de Waltari, con sus traducciones del finés y sus comentarios pertinentes sobre la vida y la obra de este destacado autor.

4 Waltari tuvo preferencia en su formación por las obras científicas de los especialistas del momento, y, sin haber estado nunca Egipto, no dejo de visitar alguno de los principales museos europeos (p. ej., los fondos de uno de los museos más destacados de Europa: el Museo de Berlín, en 1938, vid. RAJALA, op. cit., 2008, p. 487), en una búsqueda del acercamiento a lo visual, a la iconografía de las piezas del arte antiguo, como el egipcio.

5 Nombre cuyo significado es el «Hijo del Sicomoro» (S3-nh.t, Sanehet), MELTZER, E. S., «In search of Sinuhe: Sinuhe: What's In a Name? ", Paper presented at the annual meeting of the The 58th Annual Meeting of the American Research Center in Egypt, Wyndham Toledo Hotel, Toledo, Ohio, Apr 20, 2007 (2007-04-20) [fuentes: http://www.ceae.unlugar.com/meltzer.htm y http://www.allacademic.com/ meta/p_mla_apa_research_citation/1/7/5/6/1/p175615_index.htm/].

6 Sí parece que hizo uso de obras como la sueca de LANGE, H. O., Egyptiska myter och sabor med kulturhistorisk inledning, Stockholm 1925, sobre mitos y cuentos egipcios, y la de BREASTED, J. H., Geschichte Aegyptens, Zürich 1936 (vid. RAJALA, op. cit., 2008, pp. 483 ss.). En relación con el "Cuento de Sinuhé», Waltari también pudo tener presentes, entre otros, los trabajos concretos de GARDINER, A. H., Die Erzahlung des Sinuhe und die Hirtengeschichte, Leipzig 1909; GARDINER, Notes on the Story of Sinuhe, Paris 1916; ALT, A., "Zwei Vermutungen zur Geschichte des Sinuhe», ZÄS 58 (1923), pp. 48 ss.; SETHE, K., Ägyptische Lesestücke, Leipzig 1924, pp. 3 ss.; SETHE, Erlduterung zu den aegyptischen Lesestücken, Leipzig 1927, pp. 5 ss.; BLACKMAN, M., «Notes on Certain Passages in Various Middle Egyptian Texts», JEA 16 (1930), pp. 63 ss.; BLACKMAN, Middle Egyptian Stories, Brussels 1932, pp. 1 ss.; BLACKMAN, «Some Notes on the Story of Sinuhe and Other Egyptian Texts», JEA 22 (1936), pp. 35 ss. Más recientemente, seguimos a PARKINSON, R. B., The Tale of Sinuhe and other Egyptian Poems, Oxford 1998, pp. 21 ss; GALÁN, J. M., Cuatro viajes en la literatura del Antiguo Egipto, Madrid 1998, pp. 61 ss.; LICHTTHEIM, M., «Sinuhe», en The Context of Scriptum, Vol. 1., Leiden-Boston, 2003, pp. 77 ss. El propio Sinuhé de Waltari, ante uno de los últimos complot en los que está involucrado, parece aludir al Sinuhé del cuento: «Alguna vez me inclinaba a abandonarlo todo y huir a lo lejos, como mi homónimo de la leyenda, y esconderme para dejar que la suerte siguiese su curso sobre Egipto» (WALTARI, Sinuhé p. 679).

7 Egipto y otra serie de países del Oriente Próximo habían sido visitados, en particular desde el siglo XIX, por diversos viajeros de europeos. Esto había dado pie a descubrimientos de ruinas y vestigios que se documentaban mediante dibujos y diarios, lo que había servido en muchos caso de base para inicio de la primeras «excavaciones» (en algunos casos meros expolios), no con el necesario rigor y metodología arqueológica posterior. Todo ello fue proporcionando los materiales necesarios para que civilizaciones de la Antigüedad oriental, desaparecidas o de las que apenas se tenía conocimiento, fuesen investigadas con mejores medios y permitiesen el surgimiento de ciencias con personalidad propia como la Egiptología, Asiriología o la propia Hititología. Entre viajeros e investigadores iniciales en las dis- 
El libro va pues más allá del cuento original en algunos aspectos que nos interesan. Mientras el relato egipcio se centraba en los avatares de un personaje destacado de la corte que vivió en gran medida bajo el reinado de Sesostris I (Senusert I, siglo XX a.C., Dinastía XII del Imperio Medio egipcio), el Sinuhé de Waltari, reputado médico de profesión caído en desgracia, se ubica cronológicamente en un momento posterior como el Imperio Nuevo Egipcio, bajo los reinados de Amen-Hotep III, Amen-Hotep IV (Akhenatón), Smenkhkare, Tutankhamón, Ay o Horemheb, pertenecientes a la famosa Dinastía XVIII (durante el siglo XIV a.C.). En particular, tiene un lugar destacado el complejo reinado del faraón Akhenatón y el período conocido como amarniense ${ }^{8}$. Asimismo, en el cuento, la huída del Valle del Nilo y el autoexilio en el exterior no va más allá de los territorios sirio-palestinos bajo control egipcio del Reten ${ }^{9}$, frente a los diferentes países, gentes y costumbres que conoce el viajero Sinuhé de Waltari, como los Estados de Siria y Palestina, los reinos de Mitanni, Babilonia, Hatti (el País de los hititas) y, en el Egeo, Creta ${ }^{10}$.

Sin entrar a analizar lo que representa el libro en todo su conjunto en relación la historia de Egipto, podemos decir que lo narrado en el Sinuhé de Waltari nos muestra las percepciones de un médico «egipcio», aunque de oscuro origen ${ }^{11}$. Un

tintas disciplinas se pueden seleccionar algunos que pudieron ser leídos o conocidos por Waltari en su período de documentación, vid. LEPSIUS, K. R., Denkmaeler aus Aegypten und Aethiopien, Berlin 1844-1856; HUMANN, K. y PUCHSTEIN, O., Reisen in Kleinasien und Nordsyrien, Berlin 1890; RAMSAY, W. M., The Historical Geography of Asia Minor, London 1890; BREASTED, J. H., Ancient Records of Egypt, 5 vols., Chicago 1906; PETRIE, W. M. F., A History of Egypt, vol. I: From the Earliest Kings to the XVth Dynasty, y Vol. II: During the XVIIth and XVIIIth Dynasties, London 1924; LUCKENBILL, D. D., Ancient Records of Assyria and Babylonia, I-II, Chicago 1926; BREASTED, A History of Egypt from the Earliest Times to the Persian Conquest, London 1927; CONTENEAU, G., Manuel d'archéologie orientale, 4 vols., Paris 1927-1947; PIRENNE, J., Histoire des institutions et du droit privé de l'ancienne Égypte, Bruxelles 1932-35; MOORTGAT, A., Die bildende Kunst des alten Orients und die Bergvölker, Berlin 1932; ANDRAE, W., Das wiedererstandene Assur, Hinrichs, Leipzig 1938; SÄVE-SÖDERBERGH, T., Aegypten und Nubien, Lund 1941. Algunas síntesis de estos estudios iniciales en RENGER, J., «Die Geschichte der Altorientalistik und der vorderasiatischen Archäologie in Berlin von 1875 bis 1945», en Berlin und die Antike. Aufsätze, Berlin 1979, pp. 151 ss.; SIEVERNICH, G. y BUDDE, H., Europa und der Orient 800-1900, Berlin 1989; DE ROOS, J., «Early Travellers to Bo azköy», en Studio historiae ardens. Ancient Near Eastern Studies Presented to Philo H. J. Houwink ten Cate on the Occasion of his 65th Birthday, Leiden 1995, p. 261 ss.; SEEHER, J., «Travellers and Discoverers», en From Bo azköy to Karatepe: Hittitology and the discovery of the Hittite World, stanbul 2001, pp. 38 ss.

8 La nueva y efímera capital del faraón se situó en el El-Amarna (entre Menfis y Tebas) y, a pesar de su «provisionalidad», se han hallado textos cuneiformes en acadio de sus archivos internacionales con bastante información sobre este período amarniense, vid. KNUDTZON, J. A., Die El-Amarna-Tafeln, mit Einleitung und Erläuterungen, 2 vols., Leipzig 1907-15; MERCER, S. A. B., The Tell El-Amarna Tablets, 2 vols., Toronto 1939; más recientemente, CAMPBELL, E., The Chronology of the Amarna Letters, Baltimore, 1964; KÜHNE, C., Die Chronologie der internationalen Korrespondenz von El-Amarna, Neukirchen-Vluyn 1973; MORAN, W. L., The Amarna Letters, Baltimore 1992; LIVERANI, M. Le lettere di el Amarna. I. Le lettere dei «Piccoli Re» Brescia 1998; y LIVERANI, Le lettere di el Amarna. II. Le lettere dei "Grandi Re», Brescia 1999. Para los textos que se refieren a los hititas o Anatolia, Hoffner ${ }_{\mathrm{jr}}$, H. A., Letters from the Hittite Kingdom, Atlanta 2009, pp. 268 ss.

9 PARKINSON, R. B., op. cit., 1998, pp. 44 s.; GALÁN, J. M., op. cit., 1998, pp. 106 ss.

10 Un período de regionalización del Oriente Próximo antiguo, en el que las distintas potencias se disputan el poder, durante gran parte del II milenio a.C., en la última fase del Bronce (Bronce Reciente), vid. LIVERANI, M., Prestige and Interest. International Relations in the Near East ca. 1600-1100 B.C., Padova 1990.

11 Su llegada al mundo estaba plagada de misterio: «(...) llegué por el Nilo en una pequeña cesta de cañas calafateada con pez, y mi madre me encontró en los cañaverales de la ribera, en el umbral de 
Tradiciones literarias y tradiciones históricas en Sinuhé, el egipcio de Waltari...

hombre que, en su gran afán de conocimiento ${ }^{12}$, se ve superado en la mayoría de las veces por la realidad que le rodea. Alguien que huye forzadamente del «provincialismo» etnocéntrico del Egipto faraónico de la segunda mitad del II milenio a.C. que le ha tocado vivir, si bien siempre amará donde ha nacido.

El personaje de Sinuhé esboza y desarrolla ese sentimiento de búsqueda de la verdad por sí mismo y no únicamente por lo que oye o le cuentan otros, en muchos casos en forma de rumores sobre las costumbres «bárbaras» o extrañas de los Estados y/o poblaciones extranjeras. Así, muchos de los datos que, por ejemplo, son descritos en el libro sobre la civilización de los enigmáticos hititas, distinta a la egipcia, y que tienen al propio Sinuhé como el receptor de los mismos, son analizados con la perspectiva de un observador concienzudo que se plantea dudas sobre su autenticidad. Waltari, a través de su personaje principal, parece reflejar la óptica de alguien que aunque teniendo información sobre las personas, pueblos y comportamientos distintos a los del valle del Nilo tiene que indagarlos por sí mismo. Sinuhé, abierto a nuevas perspectivas, busca experimentar en persona, sobre el te-

su casa, donde me había depositado la crecida del río" (WALTARI, Sinuhé, p. 15). Más adelante, hablando con Ti(y)i, la reina viuda de Amen-Hotep III, madre de Akhenatón, parecen despejarse algunas de sus dudas al verla tejer con cañas de colores, igual que los de su canasta, y afirmar que el faraón no tuvo hijos varones de otras mujeres del gineceo real salvo su hijo (WALTARI, Sinuhé pp. 473 ss.), y canastas del mismo estilo con bebés descendieron por el Nilo. Sinuhé sigue indagando sobre el asunto, una vez muerta Ti(y)i, consiguiendo la información de que hubo un hijo de la princesa mitánnica TaduHepa, rival de Ti(y)i, que desapareció en el río por las mismas fechas que Sinuhé fue encontrado. Sinuhé pudo haber sido el hermanastro mayor de Akhenatón, pero no hay más pruebas en las averiguaciones sobre sus orígenes (WALTARI, Sinuhé pp. 491 ss.). Sin embargo, como afirma ante un sacerdote de Amón: «-El destino de Egipto estuvo quizás, el día de mi nacimiento, en unas manos negras que tejen cañas [en referencia a la reina Ti(y)i].» (WALTARI, Sinuhé p. 487); o bien un pensamiento más claro de Sinuhé, mientras observa como se disputan el trono Ai (Ay) y Horemheb: «yo era quizás el único heredero varón del trono" (WALTARI, Sinuhé p. 593). Incluso, cuando se conspira con un nuevo asesinato de Estado en el que Ai y Horemheb involucran a Sinuhé, éste afirma: «Aceptad, pues, vuestras coronas de mis manos, Ai y Horemheb, y bendecid mi nombre, porque soy yo, el humilde Sinuhé, quien os erige faraones. Esta idea me divirtió mucho, porque llevaba quizá sangre real en las venas y hubiera sido el único sucesor legal de los faraones, mientras Ai no era más que un modesto sacerdote del sol y los padres de Horemheb olían a ganado y queso" (WALTARI, Sinuhé pp. 677 s.). En síntesis, Sinuhé es un solitario que parece desplazado en todos los lugares: «-Yo, Sinuhé, soy un extranjero en este mundo, y no sé siquiera quien me engendró» (WALTARI, Sinuhé pp. 421 ss.). Esta manera de encontrar a un niño en una cesta de cañas que ha sido dejada en un río recuerda a historias como las de Moisés (Éxodo 2: 1-10) también en el Nilo, incluso la leyenda del rey acadio Sargón de Akkad hallado en el Éufrates (PRITCHARD, J. B. [ed.], The Ancient Near East: An Anthology of Texts and Pictures, Princeton University Press, New Jersey 2010, pp. 82 ss., traducción de E. A. Speiser), o algún relato legendario hitita (CTH 3), como el de la reina de Nesa/Kanes que dio a luz treinta hijos en un año y se deshizo de ellos poniéndolos en una cesta y, dejando que la corriente del Kizil Irmak (el Halys clásico) los transportase hacia su desembocadura en el Mar Negro en donde fueron recogidos y criados (vid. OTTEN, H., Eine althetitische Erzählung um die Stadt Zalpa, Wiesbaden 1973; cf. BERNABÉ, A. y ÁLVAREZ-PEDROSA, J. A. [eds.], Historia y leyes de los hititas. Textos del Imperio Antiguo. El Código, Madrid 2000, pp. 121 ss. y 126 ss.).

12 Del propio Sinuhé, en conversación con el gran sacerdote cretense, sale la afirmación: «一No me preocupo mucho de los regalos -le dije-, porque para mí el saber es más precioso que el oro, y por esto he viajado por numerosos países para aumentar mis conocimientos (...)» (WALTARI, Sinuhé p. 301), o bien, una vez que regresa a Tebas tras sus años de viajes, entre sus pensamientos afirma, a pesar de los sinsabores vividos: «(...) mi sola intención era adquirir saber (...)» (WALTARI, Sinuhé p. 347). Como establece Aziru, rey de Amurru, «amigo» de Sinuhé: «Tú, que has reunido en ti toda la cordura y el saber de los demás países, Sinuhé (...)» (WALTARI, Sinuhé p. 660). 
rreno, viajando, viendo y documentándose, con la adopción de un método de conocimiento más empírico que se aleja de la pura especulación (no importa únicamente lo que le cuentan o lo que se rumorea).

2. Lo verdaderamente sorprendente para nosotros, y por tanto susceptible de nuestro análisis, es ese retrato que del Estado de Hatti y las poblaciones hititas hizo el finlandés Waltari, y más allá, el que se los mencione en el contexto histórico apropiado de un complejo y convulso período como el de la Dinastía egipcia XVIII, punto focal del libro. Dentro de este rico mosaico plasmado por Waltari, únicamente nos centraremos en las referencias a los hititas que salpican aquí y allá su novela.

En fin, Waltari, hacia finales de los años 30 e inicios de los 40, ya podía contar como fuente con los avances que la joven Hititología proporcionaba sobre la civilización de los hititas ${ }^{13}$. Desde finales del siglo XIX se «conocía» a los hititas, si bien con una visión algo deformada tanto por su ubicación espacial como cronológica, en gran medida, debida a la mención que se hacia de ellos en el Antiguo Testamento, o bien en los textos asirios o las inscripciones monumentales egipcias ${ }^{14}$. Sin embargo, numerosos datos arqueológicos y textuales se habían ido desenterrando en los territorios por los que se había extendido su Imperio sobre las actuales Turquía

${ }^{13}$ Entre los descubrimientos arqueológicos que, desde finales del siglo XIX y, en particular, las primeras décadas del siglo XX, habían ido abriendo el camino al conocimiento de la civilización hitita, se destacan los hallazgos de innumerables tablillas con escritura cuneiforme entre las impresionantes ruinas de las inmediaciones de la actual aldea turca de Bogazköy (Bogazkale), situada en Anatolia central, a unos 150 km al E de Ankara (Turquía). Labor que recayó primero en Ernst Chantre (1893-94), pero luego, concretamente entre 1906 y 1912, en Hugo Winckler con Theodor Makridi y Otto Puchstein, y, a partir de ahí, tras una serie de importantes interrupciones bélicas (Guerra de los Balcanes, I Guerra Mundial, Guerra greco-turca o II Guerra Mundial) continuó casi ininterrumpidamente hasta la actualidad en manos de misiones alemanas (vid. GÜTERBOCK, H. G., "Resurrecting the Hittites», en Civilizations of the Ancient Near East, Vol. IV, New York-London 1995, pp. 2765 ss.; SEEHER, J., «First Excavators», «Hittite Cuneiform Specialists», «Bo azköy: Pteria?, Tavium? Hattusha! The Discovery of the Hittite Capital», «Specialists of Hittite Hieroglyphics», «Other Eminent Early Scholars», en From Bo azköy to Karatepe: Hittitology and the discovery of the Hittite World, stanbul 2001, pp. 64 ss., 88 ss., 98 ss., 116 ss. y 144 ss., respectivamente; y GONZÁLEZ SALAZAR, J. M., «Arqueología alemana en Turquía: Bogazköy/Bogazkale (Hattusa)», Hesperia. Culturas del Mediterráneo, Año V, Vol. VI [2009], pp. 173 ss.). El desciframiento de los textos, permitió conocer que la lengua que se escondía tras los textos cuneiformes pertenecía a la familia indoeuropea y no semítica (como el acadio, el babilonio o el asirio) como al principio se pensó, algo que le debemos a Bedrich(/Friedrich) Hrozný en 1915, con lo que se dio inicio a la Hititología (HROZNÝ, B., «Die Lösung des hethitischen Problems», MDOG 56 [1915], pp. 15 ss.).

${ }_{14}$ Sobre el particular, WRIGHT, W., The Empire of the Hittites, London 1884; SAYCE, A. H., The Hittites: The Story of a Forgotten Empire, London 1888; o GARSTANG, J., The Land of the Hittites, London 1910. Concretamente en el ámbito bíblico, no se los ubicaba en un reino en Anatolia sino más bien como un tipo de tribus de las regiones cananeas (citados en: Génesis X 5; XV 19-21; XXIII; XXVI 34-35; XXVII 46; XXXVI 1-2; Números XIII 29; Ezequiel XVI 3; Josué I 2-4; III 10; I Samuel XXVI 6; II Samuel XI 2-27; I Reyes X 28-29; XI 1; II Reyes VII 6-7; o II Crónicas I 17), vid. SAYCE, «Hittite and Mittannian Elements in the Old Testament», JTS 29 (1928), pp. 401 ss.; MATTER, E., Die Bedeutung der Hethiter für das Alte Testament. Eine religions-, rechtsgeschichtliche und ethnologische Studie, Bottrop in Westfalen 1933, p. 43; FORRER, E., «The Hittites in Palestine, I-Il», Palestine Explorations Quarterly 68 y 69 (1936 y 1937), pp. 190 ss. y 100 ss., respect.; BRUCE, F. F., The Hittites and the Old Testament. Tyndale Archaeology Lecture 1947, London 1947; KEMPINSKI, A., "Hittites in the Bible. What Does Archaeology Say?», BiAr 5 (1979), pp. 20 ss.; en último lugar, Hoffner ${ }_{\mathrm{jr}}$, H. A., «Hittite-Israelite Cultural Parallels», en The Context of Scriptum, Vol. 3., 2003, pp. xxix ss. 
Tradiciones literarias y tradiciones históricas en Sinuhé, el egipcio de Waltari...

y Siria ${ }^{15}$. Sin prisa pero sin pausa, estas primeras décadas de la Hititología iban dando sus frutos con la solidez de la documentación conservada, perteneciente a los vestigios materiales y, particularmente, a los textos descifrados de los hititas ${ }^{16}$. Gran parte de los datos que Waltari pudo manejar o simplemente conocer sobre los hititas, pudo provenir de obras generales o de las ediciones de los principales textos hititas, elaboradas en su mayoría por los más destacados especialitas ${ }^{17}$.

15 No fue únicamente la capital de los hititas Hattusa (Bogazköy/Bogazkale), donde se destacaron los principales hallazgos, encontramos por ejemplo las ruinas de Carchemish-Jerablus (antigua Karkemis) sobre el Éufrates, en la actual frontera entre Turquía y Siria, vid. HOGARTH, D. H., Carchemish. Report on the Excavations at Jerablus on Behalf of the British Museum. I: Introductory, London 1914; WOOLLEY, C. L., Carchemish. II: The Town Defenses, London 1921; posteriormente, WOOLLEY y BARNETT, R. D., Carchemish. III: The Excavations in the Inner Town, and the Hittite Inscriptions, London 1952; y HAWKINS, J. D., «Karkamis», RIA 5 (1980), pp. 426 ss. En general, BITTEL, K., Prähistorische Forschung in Kleinasien, Istanbul 1934; BITTEL, «Neue Funde vorklassischer Zeit aus Kleinasien», Archäologischer Anzeiger 49 (1934), pp. 349 ss.; BITTEL, «Beiträge zur kleinasiatischen Archäologie», AfO 11 (1936-37), pp. 38 ss.; y para los lugares excavados en Anatolia, MARAZZI, M., LAZZARI, A. y RE, L., L'Anatolia Hittita. Repertori Archeologici ed Epigrafici, Roma 1986.

${ }_{16}$ En general, HAZENBOS, J., «Hethitologie», en Der Neue Pauly Band 14, 2000, pp. 413 ss.; OBERHEID, R., Emil O. Forrer und die Anfänge der Hethitologie. Eine wissenschaftshistorische Biografie, Berlin 2007. Sobre algunos de los principales hititólogos también http://www.hethitologie.de/Hethitologie.de/Biografien.html.

17 No obstante, pudo tener una mayor o menor accesibilidad o interés por ellas al ser algunas extremadamente específicas. Entre la selección de publicaciones de los principales hititólogos del momento, se destacan: HROZNÝ, B., Hethitische Keilschrifttexte aus Boghazköi. In Umschrift, mit Übersetzung und Comentar, Leipzig 1919; SOMMER, F., Hethitisches, Leipzig, 1920; FRIEDRICH, J., «Die hethitische Sprache», y FORRER, E., «Die Inschriften und Sprachen des Hatti-Reiches», ambos en ZDMG 76 (1922), pp 153 ss. y 174 ss., respectivamente; ZIMMERN, H., Hethitische Texte, en Textbuch zur Religionsgeschichte, Leipzig-Erlangen 1922, pp. 331 ss.; WEIDNER, E. F., Politische Dokumente aus Kleinasien. Die Staasverträge in akkadischer Sprache aus dem Archiv von Boghazköi, Leipzig 1923; FRIEDRICH, «Der hethitische Soldateneid», ZA 35 (1924), pp. 161 ss.; GARSTANG, J., The Hittite Empire, London 1925; GOETZE, A., Hattušiliš. Der Bericht über seine Thronbesteigung nebst den Paralleltexten, Leipzig 1925a; GOETZE, «Die Hethiter, ihr Reich und ihre Kultur. Eine zusammenfassende Übersicht über den Stand der Forschung», Neue Heidelberger Jahrbücher (1925b), pp. 11 ss.; FORRER, Forschungen, I/1 y II/1, Berlin 1926; FORRER, Forschungen, I/2, Berlin 1929; FRIEDRICH, Staatsverträge des Hatti-Reiches in hethitischer Sprache, I-II, Leipzig 1926 y 1930, respect.; GOETZE, Madduwattaš, Leipzig 1928; GOETZE, Das Hethiter-Reich. Seine Stellung zwischen Ost und West, Leipzig 1928; HROZNÝ, «Hittites», Encyclopaedia Britannica, Ed. 14, Vol. XI (1929), pp. 598 ss.; CAVAIGNAC, E., «Les Annales de Muršil Il», RA 26 (1929), pp. 145 ss.; HROZNÝ, «Hethiter und Griechen», AfO 1 (1929), pp. 323 ss.; KOROŠEC, V., Hethitische Staatsverträge, Leipzig 1931; CAVAIGNAC, Les annals de Subbiluliuma, Strabourg 1931; FRIEDRICH, Hethitisch und «Kleinasiatische» Sprachen, Berlin 1931; SOMMER, Die Ahhijavā-Urkunden, Müchen 1932; GOETZE, Die Annalen des Muršiliš, Leipzig 1933; GOETZE, Kleinasien, Munich 1933; CONTENAU, G. La civilisation des Hittites et des Hurrites du Mitanni, Paris 1934; BOISSIER, A., Mantique Babylonienne et Mantique Hittite, Paris 1935; STURTEVANT, E. H. y BECHTEL, G., A Hittite Chrestomathy, Philadelphia 1935; DELAPORTE, L., Les Hittites, Paris 1936; GOETZE, Hethiter, Churriter und Assyrer, Oslo 1936; GÜTERBOCK, H. G., «Die Historische Tradition und ihre Gestaltung bei Babyloliern und Hethitern bis 1200. Zeiter Teil: Hethiter», ZA 44 (1938), pp. 45 ss.; SOMMER y FALKENSTEIN, A., Die hethitisch-akkadische Bilingue des Hattusili I (Labarna II), Munich 1938; VIEYRA, «Rites de purification hittites», RHR 119 (1939), pp. 121 ss.; ALP, S., Untersuchungen zu den Beamtennamen im hethitischen Festzeremoniell, Leipzig 1940; GOETZE, Kizzuwatna and the Problem of Hittite Geography, New York 1940; GURNEY, O. R., Hittite Prayers of Muršili II, Liverpool 1940, pp. 3 ss.; HARDY, R. S., «The Old Hittite Kingdom. A Political History», AJSL 58 (1941), pp. 177 ss.; BITTEL, K., Kleinasiatiche Studien, Amsterdam 1942; OTTEN, H., Die Überlieferungen des Telepinu-Mythus, Leipzig 1942; GARSTANG, «Hittite Militay Roads in Asia Minor. A Study in Imperial Strategy», AJA 48 (1943), pp. 35 ss. Sin olvidar las de COWLEY, A. E., The Hittites, London 1920; HOGARTH, D. G., Kings of the Hittites, London 1926; o BARTON, D. G., Hittite Studies, Paris 1928. 
En el análisis del Sinuhé de Waltari, que nos traslada con una gran clarividencia a Egipto y sus Estados vecinos durante el siglo XIV a.C., se presentan pues numerosas referencias al tema hitita como uno de los hitos del contexto histórico descrito. Una gran parte de los datos que manejó Waltari sobre el reino de Hatti de finales del Bronce (segunda mitad del II milenio a.C.) era lo que se conocía y/o se estaba investigando en el ámbito académico europeo. Waltari se adelanta a su tiempo y proporciona al lector común desde el punto de vista literario una información que, sin presentar una gran erudición, está bien documentada. No obstante, aunque Waltari describe el mundo de los hititas a veces lo adornada y deforma intencionadamente, pero también es verdad que el conocimiento que se tenía de ellos era todavía imperfecto en los tiempos en que fue escrito el libro.

2.1. En el primer tercio del libro se nos muestra un conocimiento vago del mundo hitita, sobre todo enfocado desde la perspectiva egipcia. Este conjunto inicial de informaciones tiene más que ver con lo que se cuenta de ellos, generalmente negativo, que con lo que realmente se sabe del lejano reino de Hatti (Khatti). Sinuhé sólo tiene referencias de unos desconocidos y, hasta cierto punto, amenazantes hititas del norte. No obstante, todavía no ha ido al país de los hititas.

De este modo, tras el fallecimiento del faraón Amen-Hotep III, se alude a las costumbres fúnebres y al duelo entre los grandes Estados ${ }^{18}$, incluyendo la respuesta que dan los hititas, a los que se iguala con los babilonios, todo dentro de unas prácticas generalizadas de alto nivel:

Incluso en las islas del mar se lloró la muerte del gran faraón, y el rey de BabiIonia y el del país de los Khattis [sic $]^{19}$, que reinaba sobre los hititas, enviaron a la reina madre unas tablillas de arcilla lamentando la muerte del faraón y pidiendo oro a fin de poder levantar su imagen en los templos, porque el faraón había sido para ellos como un padre y un hermano. En cuanto al rey de Mitanni, en Naharina ${ }^{20}$, envió a su hija para que se casase con el futuro faraón, como lo había hecho su padre antes que él y conforme había sido convenido con el faraón celeste antes de su muerte. Tadu-Hepa, que tal era el nombre de la princesa, llegó a Tebas con sus servidores, esclavos y asnos cargados con mercancías preciosas $(\ldots)^{21}$.

18 Desde el punto de vista de la realidad histórica de esta época, las prácticas del duelo oficial de carácter internacional podrían interrumpir, aunque no solucionar, los problemas políticos entre Estados, y fueron lo que se esperaba y aceptaba como normal en las relaciones diplomáticas de alto nivel entre los diversos reinos próximo orientales antiguos. Los datos que se poseen sobre las muestras de duelo en el Oriente Próximo se pueden resumir en el de Tusratta a la muerte de Amen-Hotep III (EA 29) que se correspondería con la que hemos mencionado de Sinuhé; el de Hattusili III a la muerte del rey babilonio-casita Kadasman-Turgu (CTH 172); o el del rey David de Israel por la muerte de Nahas (II Samuel 10), vid. ARTZI, p., «Mourning in International Relations», en Death in Mesopotamia. XXVIe Rencontre Assyriologique Internationale, Copenhagen 1980, p. 161 ss.

19 La denominación de los «Khatti(s) [=hát(t)icos]» a la que algunas veces se refiere Waltari en el texto sería errónea y haría mejor referencia a los habitantes prehititas preindoeuropeos de Anatolia que no a los propios hititas.

20 Una forma conocida en los registros egipcios para citar a Mitanni, aunque en el libro se usa erróneamente otras variantes: Naharanni o Naharani (WALTARI, Sinuhé pp. 205 y 655, respect.).

${ }^{21}$ WALTARI, Sinuhé p. 97. Es significativo que Waltari alude aquí y más adelante a otro de los elementos fundamentales en las relaciones diplomáticas entre los grandes Estados próximo orientales de fi- 
Tradiciones literarias y tradiciones históricas en Sinuhé, el egipcio de Waltari...

Una vez fuera de Egipto, cuando llega a la ciudad de Simyra (cercana a la costa siria y al valle Eleutheros) ${ }^{22}$, todo parece irle bien como médico y en sus «inversiones» en negocios de intercambio comercial, con mercancías que desde Siria partían por vía marítima hacia diversos puntos del Mediterráneo Oriental, incluyendo los puertos hititas ${ }^{23}$.

nales del período del Bronce: el matrimonio interdinástico (aquí de Amen-Hotep IV con la princesa hurromitánnica Tadu-Hepa) junto al intercambio de regalos entre las cortes reales. Incluso, más adelante, durante su estancia en Babilonia, al preguntar el rey babilonio por alguna princesa egipcia para el matrimonio, es el propio Sinuhé quien dejará claro que ninguna princesa egipcia se casa con extranjeros (una práctica habitual de la corte egipcia conocida por los historiadores, frente a la aceptación de princesas mitánnicas, babilonias o hititas que se casan con faraones): «- ¿Tiene alguna hija tu faraón? Porque después de todo lo que me has contado de Egipto he decidido pedir la mano de una hija del faraón. Cierto es que tengo ya en el gineceo cuatrocientas mujeres y que es suficiente para mí, porque no puedo ver más que una por día, y sería muy enojoso que no fueran todas diferentes, pero mi dignidad aumentaría si entre mis esposas contase una hija del faraón, y los pueblos sobre los que reino me honrarían aún más. Levanté el brazo en signo de reprobación y respondí: - Burraburiash [sic, podría referirse al conocido rey babilonio casita Burnaburiyas II, BOESE, J., «Burnaburiaš II, Melišipak und die Mittelbabylonische Chronologie», UF 14 [1982], pp. 15 ss.], tú no sabes lo que dices, porque jamás, desde que el mundo es mundo, una hija del faraón se ha unido a un extranjero porque deben casarse con sus hermanos, y si no los tienen permanecen solteras para siempre y se hacen sacerdotisas. Por esto tus palabras son una blasfemia contra los dioses de Egipto, pero te lo perdono porque no sabes lo que dices.» (WALTARI, Sinuhé pp. 228 s.). Posteriormente, hará una nueva petición: «[Burraburiash] le pedía una hija al faraón como esposa de su rey (...) la idea de enviar una hija del faraón al gineceo de Babilonia era una injuria para Egipto, porque la sangre sagrada del faraón no debe mezclarse con la sangre extranjera. Pero Akhenatón no vio en ello nada injurioso" (WALTARI, Sinuhé p. 533). Para este período del II milenio a.C. en relación a los matrimonios dinásticos y el intercambio de regalos, ZACCAGNINI, C., Lo scambio dei doni nel Vicino Oriente durante i secoli XV-XIII, Roma 1973; PINTORE, F., II matrimonio interdinastico nel Vicino Oriente durante i secoli XV-XIII, Roma 1978, pp. 11 ss., en particular para las tradiciones matrimoniales egipcias (cf. ZACCAGNINI, «On Late Bronze Age Marriages», en Studi in Onore di E. Bresciani, Pisa 1985, pp. 593 ss); ZACCAGNINI «Aspects of ceremonial Exchanges in the Near East During the Late Second Millenium B.C.», en Centre and Periphery in the Ancient World, Cambridge 1987, p. 57 ss.; LIVERANI, M., op. cit., 1990, pp. 205 ss.

22 En cuanto a Sumur/Simyra (acaso situada en Tell Kazel), KLENGEI, H., «Sumar/Simyra und die Eleutheros-Ebene inder Geschichte Syriens», Klio 66 (1984), pp. 5 ss.; SADER, H., «Tell Kazel and Ancient Simyra», Berytus 38 (1990), pp. 17 ss.; BADRE, L., et al., «Tell Kazel», Syria 71 (1994), pp. 259 ss.; BADRE, «Tell Kazel-Simyra: A Contribution to a Relative Chronological History in the Eastern Mediterranean during the Late Bronze Age», BASOR 343 (2006), pp. 65 ss.

23 «Ganaba bastante, y el oro que no utilizaba para mí o para hacer regalos lo depositaba en las casas de comercio de Simyra que mandaban navíos a Egipto, a las islas del mar y al país de Khatti, de manera que poseía partes de navíos, tan pronto una centésima parte, tan pronto cinco centésimas, según el estado de mis finanzas» (WALTARI, Sinuhé p. 167). Hay que señalar que realmente el Imperio Hitita fue continental a pesar de los puertos anatólicos como el de Ura, acaso la actual Gilindere (cerca de Aydincik), la clásica Kelenderis. Sí se puede mencionar la o las expediciones que les llevó, en el siglo XIII a.C., a la posible conquista de Chipre (la Alasiya hitita), un centro económico y comercial de primer orden, con el apoyo marítimo que provenían de los barcos sirios de aliados o vasallos como Ugarit o Amurru, entre otros, GÜTERBOCK, H. G., «The Hittite Conquest of Cyprus Reconsidered», JNES 26 (1967), pp. 73 ss. (cf. KÜMMEL, H.M., «Zwei Berichte von der Unterwerfung Zyperns durch Suppiluliama II», en TUAT I/5 [1985], pp. 492 ss.); BERNARD KNAPP, A., «KBo I 26: Alasiya and Hatti», JCS 32 (1980), pp. 43 ss.; BERNARD KNAPP, «Copper Production and Eastern Mediterranean Trade: the Rise of Complex Society on Cyprus», en State and Society. The Emergence and Development of Social Hierarchy and Political Centralization, London 1988, pp. 149 ss.; o ZACCAGNINI, C. «The Transition from Bronze to Iron in the Near East and in the Levant: Marginal Notes», JAOS 110 [1990], pp. 493 ss.); BEAL, R. H., The Organisation of Hittite Military, Heidelberg 1992, pp. 103 ss.; BEAL, «The Location of Cilician Ura», AnSt 42 [1992], pp. 65 ss.; y BRYCE, T.R., The Kingdom of the Hittites, Oxford 1998, pp. 364 ss. 
En Siria se encuentra con su «amigo» el belicoso general Horemheb ${ }^{24}$ que, observando la libertad con la que parece moverse Sinuhé por los territorios asiáticos, le propone que indague para él, a cambio de alguna compensación, sobre el poder militar de Estados rivales como el hitita:

-Muchas cosas sabes, Sinuhé -dijo Horemheb con expresión pensativa-. Eres un hombre libre y decides tus actos y viajas de una ciudad a otra oyendo cosas que los demás ignoran. Si estuviese en tu sitio y fuese libre como tú, iría a todos los países para instruirme. Iría a Mitanni y Babilonia y aprovecharía la ocasión para instruirme sobre los carros de guerra de los hititas y la manera como ejercitan sus tropas ${ }^{25}$, y visitaría también las islas del mar para ver cuál es la verdadera fuerza de los navíos de guerra de que tanto se habla. Pero yo no puedo porque el faraón me llama. Además, mi nombre es tan conocido en toda Siria que no me contarían lo que deseo averiguar. Pero tú, Sinuhé, vas vestido a lo sirio y hablas la lengua de la gente culta de todos los países. Eres médico y nadie cree que estés al corriente de otra cosa que de tu arte. Tu lenguaje es simple y a menudo infantil a mis oídos; me miras con ojos abiertos, y, no obstante, sé que tu corazón está cerrado y que no eres como te creen. ¿Es verdad?

24 Al que acompañaba como médico junto al ejército egipcio que combatía contra los nómadas en los territorios sirio-palestinos, WALTARI, Sinuhé pp. 176 ss.

25 En realidad, los datos que se manejan sobre los hititas nos permiten comprobar que contaron con un ejército poderoso. Un ejército respetado y temido formado por un grueso de infantería y, sobre todo, por el arma táctica representada por los carros ligeros de guerra tirados por caballos, considerados un medio eficaz de combate. Algunas de estas informaciones ya eran conocidas en tiempos de Waltari y pudieron ser utilizadas por él, p. ej., BONNET, H., Die Waffen der Völker der Alten Orients, Leipzig 1926; ALBRIGHT, W. F., «Mitannian maryannu, «chariot-warrior», and the Canaanite and Egyptian equivalent», AfO 6 (1930), pp. 217 ss.; HROZNÝ, B., «L'entrainement des chevaux chez les anciens indo-europeens d'après un texte mitannien-hittite provenant du 14.siècle a.J.C.», ArOr 3 (1931), pp. 431 ss. En cuanto a trabajos posteriores sobre el uso e importancia del caballo y de las unidades de carros y sus tripulaciones entre los hititas, entre otros, KAMMENHUBER, A. Hippologia Hethitica, Wiesbaden 1961; HOUWINK TEN CATE, Ph. H. J., «The History of Warfare According to Hittite Sources: The Annals of Hattusili I (Part II)». Anatolica 11 (1984), pp. 57 ss.; BEAL, R. H., op. cit., 1992, pp. 32 ss. y 141 ss.; STARKE, F., Ausbildung und Training von Streitwagenpferden, Wiesbaden 1995; MARAZZI, M., «Esercitazioni di carri da Guerra: Revisione di un passagio della Cronaca di Palazzo», en Anatolia Antica: Studi in memoria di Fiorella Imparati, Firenze 2002, pp. 507 ss.; RAULWING, «The Kikkuli Text (CTH 284). Some interdisciplinary remarks on Hittite Training Texts for chariot horses in the second half of the 2 nd millennium B.C.", en Les Équidés dans le monde méditerranéen antique, Languedoc-Rousillon 2005 [2006], pp. 61 ss. En cuanto al carro de guerra en el resto del Oriente Próximo, se puede seleccionar, LITTAUER, M. A., y CROUWEL, J. H., Wheeled Vehicles and Ridden Animals in the Ancient Near East, Leiden-Köln 1979, pp. 73 ss.; FARBER, W., «Kampfwagen (Streitwagen). A.Philologisch», y LITTAUER y CROUWEL, "Kampfwagen (Streitwagen). B. Archäologisch», ambos en RIA 5 (1976-80), pp. 336 ss. y 344 ss., respect.; SCHULMAN, R. L., "Chariots, Chariotry, and the Hyksos», Journal of the Society for the Study of Egyptian Antiquity 10 (1980), pp. 105 ss.; LITTAUER y CROUWEL, Chariots and Related Equipment from the Tomb of Tut'ankhamun, Oxford 1985; DECKER, W. «Der Wagen im Alten Ägypten», en Achse, Rad und Wagen. Fünftausend jahre Kultur-und Technikgeschichte, Göttingen 1986, pp. 35 ss.; NOBLE, D., "Assyrian Chariotry and Cavalry», SAAB 4/1 (1990), pp. 61 ss.; DREWS, R., The End of the Bronze Age: Changes in Warfare and the Catastrophe ca. 1200 B.C., Princeton 1993, pp. 104 ss. y 209 ss.; HORN, V., Das Pferd im Alten Orient. Das Streitwagenpferd der Frühzeit in seiner Umwelt, im Training und im Vergleich zum neuzeitlichen Distanz-, Reit- und Fahrpferd, Hildesheim 1995; LITTAUER y CROUWEL, «A Note on the Origin of the True Chariot», Antiquity 70 (1996), pp. 934 ss.; RAULWING y MEYER, H., «Der Kikkuli-Text. Hippologische und methodenkritische Überlegungen zum Training von Streitwagenpferden im Alten Orient», en Rad und Wagen. Der Ursprung einer Innovation. Wagen im Vorderen Orient und Europa, Mainz 2004, pp. 491 ss.; MARZAHN, J., «Pferdetraining nach Keilschrifttexten», en Pferdestärken. Das Pferd bewegt die Menschheit, Mainz 2007, pp. 45 ss. 
Tradiciones literarias y tradiciones históricas en Sinuhé, el egipcio de Waltari...

—Quizá sí -dije-. Pero, ¿qué quieres de mí?

- Si te diera mucho oro -dijo- para que pudieses ir a los países de que te he hablado a practicar tu arte y difundir el renombre de la medicina egipcia y tu reputación como sanador, en cada villa los ricos te invitarían a sus casas y podrías escrutar sus corazones, y quizá los reyes y soberanos te llamarían también y podrías sondear sus intenciones. Pero mientras ejercieras tu arte, tus ojos serían los míos y tus orejas las mías, y grabarías en tu espíritu todo lo que vieses y oyeses a fin de contármelo cuando regresaras a Egipto.

-No regresaré jamás a Egipto -dije-. Y tus proposiciones son peligrosas; no tengo interés en acabar colgado cabeza abajo de las murallas de una villa extranjera ${ }^{26}$.

Horemheb, hombre de guerra práctico, busca con insistentes argumentos que el metódico, inteligente, pero inocente Sinuhé actúe como «espía» para Egipto, o más bien para el interés personal del militar, cuyas inquietudes tienen que ver más con la conflictividad bélica que con las relaciones pacíficas entre los Estados:

(...) Lo que dices de colgarte es estúpido, porque no te pido que cometas ningún acto reprensible ni que violes las leyes de los países extranjeros. Las grandes villas, ¿no atraen acaso a los extranjeros para que visiten sus templos, no organizan fiestas y diversiones para distraer a los viajeros a fin de que éstos dejen su oro en manos de los habitantes de la villa? Si llevas oro en tus bolsillos serás bien recibido en todas partes. Y tu arte será apreciado en los países donde matan a los ancianos a hachazos o se llevan a los enfermos a morir al desierto, como lo he oído contar. Los reyes están orgullosos de su poderío y hacen desfilar sus tropas delante de ellos a fin de que los extranjeros se formen idea de su poderío. ¿Qué mal habría en que observes cómo marchan los soldados y qué armas llevan, el número de carros de guerra que tienen y si son grandes y pesados o pequeños y ligeros, y si llevan dos o tres hombres, porque han dicho que algunas veces un escudero toma sitio al lado del conductor? ${ }^{27}$ Es igualmente importante saber si los soldados están bien alimentados y brillantes de grasa, o si, por el contrario, están flacos y devorados por los parásitos o si tienen los ojos enfermos como los gatos. Se cuenta también que los hititas han descubierto por medio de la magia un nuevo metal capaz de hacer mella en el bronce mejor templado y este metal es azul y se llama hierro, pero no sé si es verdad, porque es posible que hayan encontrado simplemente un nuevo método para templar el cobre y mezclarlo pero quisiera saber de qué se trata ${ }^{28}$.

26 WALTARI, Sinuhé p. 196

27 Vid. supra.

${ }^{28}$ WALTARI, Sinuhé p. 197. Desde la Antigüedad, Anatolia ha sido lugar de origen de diversas materias primas, como la abundante madera, la piedra y su variedad metalúrgica (cobre, zinc, plomo, plata, oro o hierro) que también interesó a los propios hititas. Sin embargo, que se haya dado un amplio desarrollo del hierro (de alguna forma conocido por los hitita) y que éste, en algún momento dado, haya servido de base para el predominio militar hitita es algo que hasta el propio Waltari, puesto en boca de Horemheb, lo menciona pero lo pone en cuarentena como si fuera más bien magia o un mito. Más adelante, Sinuhé vuelve aludir a la importancia de la minería entre los hitita y al hierro: «Yo creo que la riqueza de los hititas proviene de las minas donde los esclavos y los prisioneros extraen, además del oro y el cobre, un metal desconocido que tiene un brillo gris azulado y es más duro que todos los minerales y tan caro que en Babilonia lo utilizan para hacer joyas, pero los hititas hacen armas. Ignoro cómo se puede llegar a forjar o dar forma a este metal, porque no se funde al calor como el cobre». Todavía Si- 
Antes de pasar la frontera de un gran Estado como Mitanni, llega a la localidad siria de Kades (o Qades, en hitita Kinza, sobre el Orontes) ${ }^{29}$, en manos egipcia, descrita del siguiente modo:

Acabamos llegando a la villa de Kadesh, donde había un fuerte y una guarnición egipcia. Pero las murallas no estaban guardadas ni los fosos llenos; los soldados y oficiales vivían en la villa con sus familias, sin acordarse de que eran soldados más que los días en que distribuían trigo, cebollas y cerveza ${ }^{30}$.

Kadesh era una villa tan triste y lúgubre, tan abrasada por el sol y tan desvergonzada, que incluso Kaptah se alegró de abandonarla a pesar de que temía los asnos. La única diversión era la llegada de numerosas caravanas procedentes de todos los países, porque era un importante cruce de caminos. Todas las villas fronterizas son parecidas, sean quienes sean sus soberanos, y para los oficiales y soldados son lugares de castigo, pertenezcan a Egipto, a Mitanni o a Babilonia y a Khatti, de manera que en estas guarniciones los soldados y los oficiales no hacían más que lamentarse y maldecir el día en que habían nacido ${ }^{31}$.

Cuando alcanza los territorios del reino hurrita de Mitanni (Naharina), antiguo Estado que extendió su dominio por Mesopotamia y Siria septentrional, y que en

nuhé consigue de un jefe de los guardias de puerto hitita un puñal de hierro como pago por sus servicios médicos: «-No me interesa tu oro. Pero dame el puñal que llevas en la cintura y te lo agradeceré, y así tendré un recuerdo tuyo. Pero él protestó, diciendo: - Este puñal es común, ningún lobo corre por su hoja y el puño no está plateado. Pero hablaba así porque esta arma era de metal hitita y estaba prohibido darlo o venderlo a los extranjeros, de manera que en Khatushash no había podido adquirirlo, no atreviéndome a insistir demasiado por miedo a despertar sospechas (...) acabó dándome el puñal, que era tan cortante y afilado que cortaba los pelos de la barba mejor que la más afilada navaja de sílex y podía hacer fácilmente una muesca en una hoja de cobre» (WALTARI, Sinuhé pp. 275 y 285). También aparece un puñal de hierro como regalo a Tutankhamón de una embajada hitita en la corte de Akhenatón: «Así dieron al joven Tut, yerno de Akhenatón, un puñal de un metal azul que era más brillante y cortante que todos los demás. Yo tenía un puñal idéntico que me había regalado el capitán del puerto, como he referido, y aconsejé a Tut que lo hiciese dorar y platear a la moda siria. Estuvo encantado con su regalo y dijo que habría que ponerlo en su tumba, porque era delgado y raquítico y pensaba a menudo en la muerte, más que la gente joven de su edad» (WALTARI, Sinuhé p. 563). El mismo Tutankhamon, una vez como faraón, no piensa más que en su tumba y los objetos que van a ir a ella a su muerte y el puñal será un objeto más (WALTARI, Sinuhé p. 596). Sobre el uso de los recursos metalíferos anatólicos en la Antigüedad, vid. PRZEWORSKI, S., Die Metallindustrie Anatoliens in der Zeit von 1500-700 vor Chr., Leiden 1939 (cf. BITTEL, K., AfO 15 [1945-51], pp. 114 ss.); otros estudios posteriores a la obra de Waltari son MAXWELL-HYSLOP, K. R., "Assyrian sources of Iron. A preliminary survey of the Historical and Geographical Evidence», Iraq 36 (1974), pp. 139 ss.; YAKAR, J., «Hittite involvement in Western Anatolia», AnSt 26 (1976), pp. 117 ss.; De JESUS, p. S., «Metal resources in Ancient Anatolia», AnSt 28 (1978), pp. 97 ss.; De JESUS, The Development of Prehistoric Mining and Metallurgy in Anatolia, Oxford 1980; YENER, K. A., "The Production, Exchange and Utilization of Silver and Lead Metals in Ancient Anatolia: A Source Identification Proyect», Anatolica 10 (1983), pp. 1 ss.; MUHLY, J. D., et al., «Iron in Anatolia and the Nature of the Hittite Iron Industry», AnSt 35 (1985), pp. 67 ss.; KOŠAK, S., «The Gospel of Iron», en Kaniššuwar. A Tribute to H. G. Güterbock on His Seventy-fifth Birthday May 27, 1983, Chicago 1986, pp. 125 ss.; SIEGELOVÁ, J., «Metalle und Metallugie. A.II. In den heth. Texten», RIA 8 (1993), pp. 112 ss.; o KAPTAN, E., «Tin and Ancient Mining in Turkey», Anatolica 21, 1995, pp. 197 ss.

29 En el actual Tell Nebi Mend, DAVEY, C., «Qadesh on the Orontes», Buried History 12 (1976), pp. 14 ss.; KUSCHKE, A., «Qadesh», Lexikon der Ägyptologie V (1984), pp. 27 ss.; URIEL, F., «Kadesh. El problema continuado», Espacio, tiempo y forma. Serie II, Historia Antigua 7 (1994), pp. 429 ss.

30 WALTARI, Sinuhé, p. 204.

31 WALTARI, Sinuhé, p. 205. 
Tradiciones literarias y tradiciones históricas en Sinuhé, el egipcio de Waltari...

estos momentos esta viviendo momentos de decadencia ${ }^{32}$, comienza a hacer lo que le ha pedido Horemheb. Cada vez que va descubriendo de nuevas informaciones, va siendo mayor el interés de Sinuhé por conocer a los hititas:

Pero, cumpliendo órdenes de Horemheb, conversé con los notables y los humildes y todos me dijeron lo mismo y yo comprendía que estuviesen inquietos. Porque un día el país de Mitanni había sido poderoso, pero ahora se encontraba entre Babilonia al Este, los pueblos bárbaros al Norte y los hititas al Oeste, en el país de los Khatti. Cuanto más oía hablar de los hititas, a quienes temían, mejor comprendía que debía ir también al país de Khatti, pero antes quería visitar Babilonia ${ }^{33}$.

Con todo ello, lo que llega a sus oídos sobre los hititas, narrado por los habitantes de Mitanni, no es demasiado positivo. Sin embargo, a pesar de lo que puedan decir sobre los hititas, Sinuhé no parece que dé muestras de aceptarlo ciegamente y lo que escribe lo pone siempre en boca de los mitánnicos. Realmente, la rivalidad por el control político regional entre ambos Estados, Hatti y Mitanni, está pasando por los momentos más álgidos y no es de extrañar que entre enemigos lo que se diga del otro no tiene que ser bueno:

Debo consignar también que los habitantes de Mitanni ignoraban las fronteras exactas de su país, porque los mojones se desplazaban incesantemente, los hititas se los llevaban en sus carros para levantarlos en otro sitio a su antojo. Si lo que contaban de los hititas era verdad, no existía en el mundo un pueblo más cruel y más temible. Según ellos, los hititas no tenían mayor placer que escuchar los gemidos de los torturados y ver correr la sangre, cortaban las manos de los habitantes fronterizos que se quejaban de que los rebaños de los hititas pisoteaban sus campos y pacían el trigo joven, y después se burlaban de ellos diciéndoles que volviesen a poner los mojones en su sitio. Les cortaban también los pies y les decían que corriesen a quejarse a su rey y les soltaban la piel del cráneo para bajársela delante de los ojos para que no viesen cómo cambiaban de sitio los mojones. Los habitantes de Mitanni pretendían que los hititas se mofaban de los dioses de Egipto, lo cual era una terrible ofensa para todo el país, y esto solo hubiera sido motivo para que el faraón mandase oro, armas y mercenarios a fin de resistir por la fuerza a los hititas; pero a la gente de Mitanni no le gustaba la guerra y esperaban que los hititas se retirarían al ver que el faraón sostenía Mitanni. No puedo repetir aquí todo el mal que los hititas les hubieran causado ni las crueldades y horrores cometidos por ellos. Pero decían que eran peores que la langosta, porque después del paso de la langosta el suelo reverdece, pero sobre el rastro de los carros hititas la hierba no vuelve a crecer ${ }^{34}$.

Únicamente en el momento en que Sinuhé llegue al territorio hitita será él mismo quien proceda a describir lo que vea, y hablará con conocimiento de causa. Así, tras haber visitado el reino de Babilonia ${ }^{35}$, vuelve a pasar por los territorios de

32 En realidad, es el preludio de la caída de Mitanni a manos de los hititas. Sobre los hurritas y el estado de Mitanni, entre otros, WILHELM, G., Grundzüge der Geschichte und Kultur der Hurriter, Darmstadt 1982; WILHELM, «The Kingdom of Mitanni in second-millennium Upper Mesopotamia», en Civilizations of the Ancient Near East, New York-London, 1995, Vol. II, pp. 124 ss.

33 WALTARI, Sinuhé, p. 206.

34 WALTARI, Sinuhé, pp. 208 ss.

35 WALTARI, Sinuhé, pp. 211 ss. 
Mitanni antes de partir hacia Hatti. De nuevo el interés por los hititas se hace patente en Sinuhé por diversos motivos, no únicamente relacionados con el conocimiento. Sabe que su viaje se prolongará posteriormente más allá, hacia el Egeo, en Creta (Keftiu) ${ }^{36}$ de donde es su compañera de viaje, Minea. En este punto, sí es notable la alusión a un pago de tributo por parte de Mitanni, con lo que se puede pensar que el antiguo estado hurrita, que en su momento había sido rival de Egipto, ahora, siguiendo la práctica diplomática al uso ${ }^{37}$, es un «vasallo», aunque de primer orden, de la nueva potencia naciente, Hatti:

- Sé que echas de menos tu dios y tu país ${ }^{38}$ y que nos espera un largo viaje. Pero, por razones que no te puedo exponer, debo ir primero al país de Khatti, donde viven los hititas. Después de haber interrogado a los mercaderes, los viajeros y los hoteleros he recogido muchos informes que son a menudo contradictorios, pero creo que desde el país de Khatti podremos embarcar para Creta y, si lo quieres, te llevaré a la costa de Siria de donde parten cada semana los barcos para Creta. Pero me he enterado de que en breve saldrá una embajada para llevar el tributo anual de los mitannianos [sic] al rey de los hititas y con ella podremos viajar en seguridad y ver y conocer muchas cosas que ignoramos, y esta ocasión no se me volverá a presentar hasta dentro de un año. No quiero, sin embargo, imponerte una decisión; tómala tú misma.

En mi corazón yo sabía que mentía, porque mi proyecto de visitar el país de los Khatti no estaba inspirado más que en el deseo de conservarla el mayor tiempo posible a mi lado (...).

36 Sobre los Keftiu en las fuentes egipcias, algo tratado por los especialistas antes de la obra de Waltari, vid. WAINWRIGHT, G. A., "The Keftiu-People of the Egyptian Monuments», Liverpool Annals of Archaeology and Anthropology 6 (1914), pp. 24 ss. Más recientemente, sin agotar el tema, SAKELLARAKIS, J. y E., «The Keftiu and the Minoan Thalassocracy», en The Minoan Thalassocracy: Myth and Reality, Stockholm 1984, pp. 197 ss.; o HOOD, s., «Crete, Syria and Egypt», en Krete-Aigyptos: Politismikoi desmoi trion chilietion, Athens 2000, pp. 21 ss.

${ }_{37}$ La cancillería hitita uso unos mecanismos muy complejos y elaborados. Algunos ejemplos de este comportamiento diplomático se reflejan en los tratados hititas, que se convierten en el documento oficial que podía estar redactado en acadio, como lengua internacional (o lingua franca) aceptada por todos, y en la propia lengua hitita, vid. DEL MONTE, G., «Traduzione e interferenza nei trattati siro-hittiti», VO 3 (1980) pp. 103 ss.; sobre la diferencia de estos tratados de vasallaje con los de paridad, ZACCANIGNI, C., «The Forms of Alliance and Subjugation in the Near East of the Late Bronze Age», en I trattati nel Mondo Antico. Forma, ideologia, funzione, Roma 1990, pp. 46 ss. y 67 ss.; ALTMAN, A., «Rethinking the Hittite System of Subordinate Countries from the Legal Point of View», JAOS 123 (2003), pp. 741 ss. (asimismo, KOROŠEC, V., op. cit., 1931, pp. 11 ss.; KOROŠEC, International Relations According to Cuneiform Report from Tall al-Amarna and Hittite State Archives, Ljubljana 1950; KESTEMONT, G., Diplomatique et droit internationale en Asie Occidentale [1600-1200 av. J.C.], Louvain-La-Neuve 1974; KESTEMONT, «Les grands principes de droit international regissant les traites entre les Etats procheorienteaux des XVe-XIIle s. av. J. C.», en Mesopotamien und seine Nachbarn, 1982, pp. 269 ss.; IMPARATI, F. en Klengel, H., Geschichte des Hethitischen Reiches, Leiden 1999, pp. 358 ss.). El vasallo tenía una serie de obligaciones que se le imponían en el tratado: apoyo militar contra enemigos externos e internos de Hatti, tránsito de tropas, mantenimiento de guarniciones, asuntos de fugados o exiliados y su restitución, denuncia de posibles conspiraciones, pago de tributos, reconocimiento de la sola autoridad del monarca hitita, etc., son algunas de las cláusulas que aparecen invariables en los textos (p. ej., DEL MONTE, Il trattato fra Muršili II di Hattuša e Niqmepa di Ugarit, Roma 1986, pp. 10 ss.; cfr., LIVERANI, M. op. cit., 1990, pp. 267 ss., para los tributos). Entre los tratados conservados: con Amurru, CTH 49, 62, 92, 105; Halap/Alepo, CTH 75; Karkemis, CTH 50, 122; Mitanni, CTH 51, 52; Nuhhase, CTH 53; o con Ugarit, CTH 46, 66, entre otros textos (BECKMAN, G., Hittite Diplomatic Texts, Atlanta 1996).

38 Son las palabras de Sinuhé a su compañera de viaje, Minea. 
Tradiciones literarias y tradiciones históricas en Sinuhé, el egipcio de Waltari...

(...) debo decirte que según todos los informes los hititas son un pueblo cruel, de manera que durante el viaje nos amenazarán muchos peligros y aun la muerte. Por esto harías mejor en esperarnos en Mitanni y te dejaré suficiente oro para vivir convenientemente ${ }^{39}$.

2.2. Es el momento de encaminarse desde las fronteras de Mitanni hacia Hatti $^{40}$. A partir de ahora la actitud de Sinuhé será la del testigo directo. Las posibles incorrecciones sobre los hititas narradas por el personaje tienen que ver con el mayor o menor conocimiento que sobre la materia tenía Waltari, o bien sobre su deseo de novelar y hacer más ficticio lo que pretende describir, exagerando lo que le interesa primar o no de los hititas ${ }^{41}$.

Aunque, finalmente se decide acompañarlo, no tiene muy claro por qué ruta: «- ¿Crees acaso posible que deje a mi dueño ir solo al país de los Khatti? Sería como meter a un cordero recién nacido en una perrera y mi corazón no cesaría de reprocharse un crimen parecido. Por esto te ruego que me contestes francamente a una pregunta: ¿Vamos al país de los Khatti por mar? Le dije que a mi modo de entender no había mar entre Mitanni y el país de los Khatti, pese a que los informes fuesen inciertos, pero que el viaje sería probablemente largo »42.

El inicio del trayecto comienza con la declaración de intenciones de Sinuhé, sus primeras apreciaciones sobre los hititas y los duros aspectos geoclimáticos de Anatolia, además de otras consideraciones generales de su organización:

He referido ya lo que se decía de los hititas en el país de Mitanni y en adelante me limitaré a exponer lo que he visto con mis ojos y sé que es exacto. Pero ignoro si se me creerá, tal es el terror que el poderío hitita ha inspirado en todo el mundo y tales son los horrores que se cuentan sobre ellos. Y, sin embargo, tienen cualidades también y puede uno instruirse con ellos, pese a que sean de temer. En su país no reina el desorden, como se ha dicho, sino un orden estricto y una disciplina, de manera que el viaje por sus montañas es seguro para el que ha obtenido un

39 WALTARI, Sinuhé, pp. 271 ss.

40 «Así fue como decidí unirme a la embajada real como médico para llegar con seguridad al país de los Khatti» (WALTARI, Sinuhé p. 272).

${ }^{41}$ El sirviente de Sinuhé, Kaptah, deja claro su temor: «Todo el mundo sabe que los hititas son como bestias feroces que se alimentan de carne humana y sacan los ojos a los extranjeros para hacerles dar vueltas a sus pesadas muelas" (Waltari, Ibidem). Por lo que respecta a cegar prisioneros y vincularlos a las tareas de molienda más adelante se suele aludir a esta costumbre: «He observado que las muelas de vuestros molinos son movidas por esclavos con los ojos arrancados» (p. 280); la justificación hitita es: «Por pura filantropía arrancamos los ojos a los esclavos condenados a empujar las muelas de los molinos, porque es un trabajo muy penoso y les parecería más penoso aún si viesen el cielo y la tierra y los pájaros en el aire. Esto les daría vanas ideas y habría que condenarlos a muerte por sus tentativas de evasión» (p. 281); y, finalmente, al partir de la capital hitita: «(...) pasamos montados en unos asnos cerca de los ruidosos molinos movidos por los esclavos ciegos» (p. 283). Este tema no fue extraño entre los hititas y en otros pueblos del Oriente Próximo, e incluso en el Antiguo Testamento aparece mencionado con Sansón (Jueces XVI 21). Aparte de un trabajo que estamos preparando sobre este particular, vid. HOFFNER ${ }_{\mathrm{j}}, \mathrm{H}$. A., «The Treatment and Long-Term Use of Persons Captured in Battle», en Recent Developments in Hittite Archaeology and History. Papers in Memory of Hans G. Güterbock, Winona Lake 2002, pp. 61 ss.

42 WALTARI, Sinuhé p. 273. 
salvoconducto, hasta el punto de que si un viajero desaparece o es desvalijado por el camino, el rey le indemniza el doble de sus pérdidas, y si el viajero perece a manos de los hititas, el rey, de acuerdo con una tabla especial, paga a los parientes una suma correspondiente al valor de lo que ganaba el difunto ${ }^{43}$.

Por esto el viaje en compañía de los enviados del rey de Mitanni fue monótono y sin incidentes, porque los carros de guerra hititas nos escoltaron velando para que tuviésemos vituallas y bebidas en las etapas. Los hititas son gente dura y no temen ni el frío ni el calor, porque habitan las montañas áridas y deben desde la infancia acostumbrarse a las fatigas impuestas por el clima ${ }^{44}$. Por esto son gente sin miedo en el combate y no se perdonan, y desprecian a los pueblos blandos y los someten, pero respetan a los valientes y fuertes buscando su amistad.

Su pueblo está dividido en numerosas tribus y poblados, gobernados soberanamente por príncipes, pero estos príncipes están sometidos a su gran rey ${ }^{45}$, que vive en la villa de Khatushash, en medio de las montañas. Es su sumo sacerdote, su jefe supremo y su gran juez, de manera que acumula toda la soberanía, y no conozco ningún otro rey que posea un poder tan absoluto. En efecto, en los otros países, como en Egipto, los sacerdotes y los jueces determinan los actos del rey más de lo que él cree.

Durante este viaje inicial de Sinuhé hacia los territorios bajo influencia de Hatti tuvo como lugar de paso la importante localidad de Karkemis ${ }^{46}$, sobre el curso del Éufrates. Es significativo que, desde finales del s.XIV a.C., los hititas establecieron un «protectorado» sobre la extensa superficie conquistada en Siria septentrional.

${ }^{43}$ Existió entre los hititas en realidad una clara legislación (vid. infra) en caso de fallecimiento de mercaderes, si bien bajo otros términos (Leyes $\S \S 5$ y III), vid. HOFFNER, $\mathrm{H}$. A., The Laws of the Hittites. A Critical Edition, Leiden-New York-Köln 1997, p. 19 s.; BERNABÉ y PEDROSA, Historia, 2000, p.

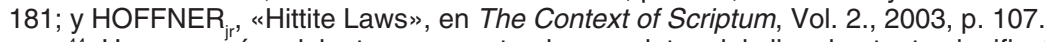

44 Un poco más adelante nos cuenta algunos datos del clima bastante significativos de lo que sucede en Anatolia en relación con Siria-Palestina o el propio Egipto: «Atravesando las regiones fronterizas dominadas por las guarniciones que saquean los países vecinos y cambian a su antojo los jalones para asegurarse un sueldo, nadie podría sospechar la riqueza del país hitita, y menos todavía sus montañas estériles que el sol abrasa en verano, pero que en invierno se cubre con plumas frías, según me han dicho, pero que no he visto. Estas plumas caen del cielo y cubren el suelo, fundiéndose en agua cuando llega el verano. He visto tantas cosas sorprendentes en el país de los hititas que doy crédito a este relato, por más que no comprenda cómo las plumas pueden convertirse en agua. Pero de lejos he visto las montañas cubiertas de estas plumas blancas" WALTARI, Sinuhé pp. 274 ss. Sobre algunos de los aspectos geoclimáticos anatólicos, GONZÁLEZ SALAZAR, J. M., «Aproximación al estudio regional de los sectores montañosos de Anatolia septentrional (Geographia Antolica Antiqua)», Boletín de la Asociación Española de Orientalistas (=BAEO) 42 (2006), pp. 59 ss.

45 No es una descripción que se asemeje a lo que se conoce para los hititas, que más bien poseían una estructura centralizada con un destacado poder del monarca hitita en todos los ámbitos (político-militar, administrativo-judicial o religioso). Temas como la división en tribus se podría relacionar más con la concepción originaria que se tenía de los hititas a través del Antiguo Testamento (vid. supra). Para una discusión sobre la organización interna del estado hitita y los intentos de clasificación de su sociedad, en la que no parece caber la existencia de algo similar al «feudalismo», vid. ARCHI, A., «ll «feudalesimo» ittita», SMEA 18, 1977, pp. 7 ss.; IMPARATI, F., «Aspects de l'organisation de l'État Hittite dans les documents juridiques et administratifs», JESHO 25 (1982), pp. 249 ss.; o IMPARATi, «Lehenswesen», RIA 7-8 (1983), pp. 543 ss.; y recientemente, GONZÁLEZ SALAZAR, J. M., «Introducción a la civilización hitita», en Vida y costumbres en el Oriente Próximo, Madrid, 2007, pp. 21 ss. y 46 ss.

${ }_{46}$ Sobre las excavaciones en el lugar, vid. supra. En la actualidad se ha abierto la posibilidad de reabrir los trabajos arqueológicos allí, o bien en manos de una misión italiana o bien japonesa. No obstante, los vestigios conservados pertenecen a la ciudad del I milenio a.C., más que a la de época hitita. 
Tradiciones literarias y tradiciones históricas en Sinuhé, el egipcio de Waltari...

En este sistema de control territorial, Karkemis, tomada a Mitanni, ejerció su poder en nombre de Hatti como cabeza de un virreinato en manos de miembros de la familia real hitita. Su posición privilegiada en el mapa geopolítico, permitió que los virreyes hititas de Karkemis, con cierta autonomía, llevasen un control férreo de la situación frente a posibles revueltas en el corazón de Siria y Mesopotamia septentrional, antigua zona de influencia del Estado hurrita de Mitanni, o al peligro siempre latente de Egipto desde el sur ${ }^{47}$.

En la llanura desolada de la frontera siria tienen la fortaleza de Karchemish, cuyas murallas están construidas con piedras enormes y cubiertas de imágenes espantosas. Allí es donde recaudan los impuestos sobre todas las caravanas y los mercaderes que cruzan su país, y así amontonan abundantes riquezas, porque los impuestos son pesados y Karchemish está situada en un cruce de numerosas rutas de las caravanas. Quien haya visto esta fortaleza alzarse espantosa sobre la montaña, a la luz del crepúsculo matutino, en medio de la llanura en la cual los cuervos se precipitan para roer cráneos y huesos blanqueados por el sol, creerá lo que cuento de los hititas y no dudará de mis palabras. Pero no permiten a las caravanas y a los mercaderes atravesar su país más que por algunos caminos determinados, y a lo largo de estos caminos los poblados son pobres y mezquinos y los viajeros ven tan sólo algunos raros campos cultivados, y si alguien se aparta del camino autorizado, es aprisionado y desvalijado y llevado como esclavo a las minas.

La llegada al corazón de Anatolia y, por ende, a la sede del poder imperial de Hatti tiene su punto culminante ante la ciudad de Hattusa. Ésta fue una de las más destacadas capitales del Oriente Próximo durante finales del Bronce (en particular en los siglos XIV y XIII a.C.), situada entre montañas, aparece dotada de múltiples templos (la ciudad de los «mil dioses de Hatti» como aparece en los textos) ${ }^{48}$, el palacio real sobre la acrópolis (Büyükkale) y unas elaboradísimas fortificaciones que la circundaban ${ }^{49}$. Así, el viajero Sinuhé se ajusta en sus percepciones a lo que en realidad llegó a ser la capital de los hititas:

47 Para áreas fronterizas concretas como Siria y el importante papel de los hititas a partir del ascenso al trono de Suppiluliuma (vid infra), GONZÁLEZ SALAZAR, J. M., "Quelques considèrations sur l'Euphrate comme ligne de frontière pendant le royaume hittite, XIV-XIII siècles av. J. C.», en Studies for Ancient Near Eastern Cultures. Metin Akyurt Bahattin Devam in Memoriam, Istanbul 1995, pp. 299 ss.; GONZÁLEZ SALAZAR, «Hatti y Egipto. Algunos aspectos de los contactos entre dos grandes reinos durante el Bronce Tardío», Boletín de la Asociación Española de Egiptología (BAEE) 7 (1997), pp. 111 ss.; GONZÁLEZ SALAZAR, «Los problemas del control del territorio en el mundo hitita. Reflexiones sobre la frontera oriental del reino de Hatti», en Actas del Congreso Español de Antiguo Oriente Próximo: «El Mediterráneo en la Antigüedad: Oriente y Occidente" (Madrid, 29 de Septiembre-2 de Octubre 1997), publicado en CD ROM, Madrid 1998; o GONZÁLEZ SALAZAR, «Elementos esenciales de las relaciones de alto nivel entre las casas reales hitita y egipcia (primera mitad del s. XIII a.C.). Manipulación y propaganda celebrativa», BAEE 8 (1998), pp. 107 ss.

48 SINGER, I.," «The Thousand Gods of Hatti»: The Limits of an Expanding Panteón», en Concepts of the Other in Near Eastern Religions, Leiden 1994, pp. 81 ss.; o KARASU, C., "Why did the Hittites have a Thousand Deities? », en Hittite Studies in Honor of Harry Hoffner Jr. on the Occasion of His 65th Birthday, Winona Lake 2003, pp. 221 ss.

49 Waltari pudo conocer los destacados trabajos que los alemanes realizaban en la ruinas de Bogazköy/Bogazkale, desde inicios del siglo XX, y, en particular, con las excavaciones más sistemáticas desde el año 1931 a manos de Kurt Bittel (1931-1977), con el respaldo conjunto de la Deutsche Orient- 
Y voy a referir cómo es su capital en medio de las montañas, pese a que sepa que no se me creerá si se lee mi relato ${ }^{50}$.

Cuando se citan las grandes ciudades del mundo se habla de Tebas y Babilonia y algunas veces de Nínive, pese a que no he estado, pero nadie habla nunca de Khatushash [sic], que es la capital de los hititas y el hogar de su poderío, como el águila posee su nido en las montañas en el centro de terrenos de caza. Y, sin embargo, esta villa, por su poderío, resiste las comparaciones con Tebas y Babilonia, y cuando se piensa que sus inmensos edificios altos como las montañas están construidos con piedras talladas y sus murallas no pueden derrumbarse y son más sólidas que todas las que he visto, estimo que esta villa es una de las maravillas del mundo, porque no esperaba ver lo que en ella descubrír1.

Los siguientes elementos descriptivos de Sinuhé son más una concesión literaria del propio Waltari. En la mayoría de los casos, la información que proporciona sobre comportamiento o su aspecto físico se mueven en el terreno de la especulación y no se ajusta a la realidad ${ }^{52}$. Muy poco sabemos realmente de cómo eran

Gesellschaft y del Deutsches Archäologisches Institut. Posteriormente, éstas han continuado con Peter Neve (1978-1994), Jürgen Seeher (1994-2005) y Andreas Schachner (desde 2005), vid. BITTEL, K., Die Ruinen von Bogazköy, der Hauptstadt des Hethiterreiches. Kurze Beschreibung, Berlin 1937; Bittel, Hattusha. The Capital of the Hittites, New York 1970 (también Hattuscha. Hauptstadt der Hethiter. Geschichte und Kultur einer altorientalischen Grossmacht, Köln 1983); BITTEL, «Hattuša», RIA 4 (1972-75), pp. 162 ss.; BITTEL, "Quelques remarques archéologiques sur la topographie de Hattuša», Comptes Rendus (des séances de l')Académie des inscriptions et Belles-Letres, Paris 1983, pp. 485 ss.; NEVE, Hattuša-Stadt der Gotter und Tempel. Neue Ausgrabungen in der Hauptsadt der Hethiter, Mainz 1993; SEEHER, J., Hattuscha-Führer. Ein Tag in der hethitischen Hauptstadt, Istanbul 2002; GONZÁLEZ SALAZAR, J. M., op. cit., 2009, pp. 173 ss.; GONZÁLEZ SALAZAR, «A propósito de las recientes excavaciones en la capital de los hititas: El proyecto Bogazköy-Hattusa», BAEO 45 (2009), pp. 213 ss.

50 WALTARI, Sinuhé, p. 274.

51 WALTARI, Sinuhé, pp. 275 ss.

52 «Pero el misterio de esta villa estriba en que el rey ha prohibido el acceso a ella a los extranjeros, de manera que sólo son admitidos los enviados de los reyes portadores de regalos, y se les vigila estrechamente durante su estancia. Por esto los habitantes no hablan con los extranjeros aunque entiendan su lengua, y si se les hace una pregunta contestan: «No lo sé» o "No entiendo», y miran a su alrededor, con miedo, para ver si alguien les ha visto hablar con el extranjero. No obstante, las vestiduras de sus nobles y grandes son tan bellas como las de los extranjeros y enviados, porque les gustan mucho las ropas abigarradas y bordadas de oro y plata, y como insignias llevan almenas y un hacha doble que son los emblemas de sus dioses. Sobre sus trajes de fiesta se ve también algunas veces un disco alado. Llevan botas de cuero flexible y pintado o zapatos con la punta larga y levantada, tienen unos altos sombreros puntiagudos y sus mangas son muy largas, llegando a veces hasta el suelo, y unos trajes también muy largos y plisados. Se diferencian de los habitantes de Siria, Mitanni y Babilonia en que llevan el mentón afeitado a la moda egipcia y algunos nobles se afeitan también el cráneo, no dejando sobre la cabeza más que un mechón de cabellos que trenzan. Tienen la barbilla fuerte y vigorosa, y la nariz es larga y ganchuda como las aves de rapiña. Los nobles y los grandes que viven en la ciudad son gordos, y su rostro es reluciente, porque están acostumbrados a una alimentación abundante» (WALTARI, Sinuhé p. 276). Incluso: «Las costumbres de los hititas son austeras, y un noble no puede mostrarse embriagado en la calle sin perder su reputación, pero, como en todas partes, los nobles y los grandes bebían mucho vino, y también unos pérfidos vinos mezclados, y los curé de los males producidos por el vino y los liberé del temblor de las manos cuando debían presentarse delante del rey, y a algunos les prescribí baños y calmantes cuando me decían que los ratones les roían el cuerpo. Permití también a Minea bailar delante de ellos y le hicieron muchos regalos sin exigirle nada, porque los hititas son muy generosos cuando alguien les gusta» (WALTARI, Sinuhé, pp. 278 ss.). O bien, cuando una embajada hitita llega a visitar a Akhenatón se los describe así: «Estos jefes hititas eran hombres bellos, agradables e instruidos. Su nariz aguileña, su mentón enérgico y sus ojos de animal feroz les procuraron numerosos éxitos, porque las mujeres se entusiasman fácilmente con todo lo que es nuevo" (WALTARI, Sinuhé p. 563). Así, el propio 
Tradiciones literarias y tradiciones históricas en Sinuhé, el egipcio de Waltari...

y qué llevaban los hititas, salvo lo que se conoce de las representaciones de sus relieves, generalmente no muy abundantes y pertenecientes al ámbito sagrado del poder. No hay comparación con los innumerables datos que se conservan de pueblos como el egipcio.

Según Sinuhé la organización de la sociedad hitita tiene un alto componente militar, con una capital que canaliza sus esfuerzos en la «industria» armamentística. Todo ello indicaría que se está ante un reino fuertemente militarizado, como una visión demasiado exagerada pero que está al mismo tiempo acorde con la idea de Waltari sobre un Estado hitita agresivo frente a sus vecinos (p. ej., el Egipto que nos presenta de Akhenatón).

No reclutan mercenarios, como los pueblos civilizados, sino que son todos soldados y se reparten entre sí los grados, de manera que los más elevados son los que pueden sostener un carro de guerra, y el rango no se fija según el nacimiento, sino según su habilidad en el manejo de las armas. Por esto todos los hombres se reúnen una vez al año bajo el mando de sus jefes y sus príncipes para hacer ejercicios militares. Khatushash no es una villa comerciante como todas las demás grandes ciudades, sino que está llena de talleres y forjas de donde sale sin cesar un estruendo de metal, porque forjan las puntas de las lanzas y las flechas, así como ruedas y cureñas de carros de guerra ${ }^{53}$.

En realidad, los hititas fueron una gran potencia militar y su ejército fue uno de los más poderosos durante los siglos XIV y XIII a.C., pero no fue lo único que les permitió mantener y expandir su poder imperial. Fueron pues capaces de combinar la fuerza armada con la diplomacia de alto nivel ${ }^{54}$.

Entre los aspectos judiciales hititas de los que Sinuhé habla, se presentan algunos datos inexactos, que Waltari pudo utilizar como recurso para mostrar a un pueblo hitita sorprendentemente peculiar en alguna de sus costumbres en compasión con lo que su personaje Sinuhé conoce de Egipto y/o de otros lugares que ha recorrido 55 :

hijo de Suppiluliuma: «(...) era joven y altivo, y sus ojos eran grandes y claros como el agua (...). La alegría y la curiosidad animaban su rostro cetrino y su nariz era firme como el pico de un ave de rapiña y sus dientes relucían de blancura como los de las fieras" y "era verdaderamente un hombre bello, y yo no podía olvidar su risa altiva y juvenil, ni sus dientes de un resplandor tan blanco" (WALTARI, Sinuhé pp. 681 y 687, respect.). En general, sí parecía, p. ej., que podían ir rasurados y llevar vestimentas y un calzado determinado. También es verdad que existieron símbolos como el disco solar alado, aunque no es tan cierto el uso de la almena y un hacha doble (en este caso más del Egeo). Algunos de estos aspectos en GONZÁLEZ SALAZAR, J. M., op. cit., 2007, pp. 42 ss. y 59 ss.

53 WALTARI, Sinuhé, pp. $276 \mathrm{~s}$.

54 Los aspectos militares y diplomáticos hititas en referencias previas. En cuanto a que no hacían uso de mercenarios, hay que replantearlo estableciendo que, por lo que conocemos, los hititas utilizaron tropas de apoyo de los Estados vasallos y aliados cuando fueran necesarias tal como muestran los tratados que se han conservado (vid. supra).

55 Waltari puede haber consultado algunos datos de las primeras ediciones del «Corpus» (que no código como se pensaba en un primer momento) de leyes hititas, si bien dándole una perspectiva adaptada a sus intereses, vid. HROZNÝ, B., Code Hittite provenant de l'Asie Mineure (vers 1350 av. J.C.). Ier partie. Transcription, traduction française, Paris 1922; ZIMMERN, H. y FRIEDRICH, J., Hethitische Gesetze aus dem Staatsarchiv von Boghazköi (um 1300 v. Chr.), Leipzig 1922; GOETZE, A., «Zur Interpretation der hethitischen Gesetze», ZA 36 (1925), pp. 254 ss.; WALTER, A., «The Hittite Code», en 
Su justicia difiere también de la de todos los demás pueblos porque sus castigos son extraños y ridículos. Así si un príncipe intriga contra el rey para destronarlo no es condenado a muerte, sino que es mandado a la frontera para que adquiera mérito y mejore su reputación ${ }^{56}$. Y no hay casi crimen que no pueda expiarse con multas, porque un hombre puede matar a otro sin ser condenado a muerte y debe sencillamente indemnizar a los parientes de la víctima ${ }^{57}$. No castigan tampoco el adulterio, porque si una mujer encuentra un hombre que le guste más que su marido, tiene el derecho de abandonar el hogar, pero el nuevo marido debe indemnizar al primero. Los matrimonios estériles son anulados públicamente, porque la ley exige a los súbditos muchos hijos ${ }^{58}$. Si alguien mata a otro en un lugar desierto, no tiene que pagar tanto como si la muerte ha tenido efecto en la ciudad y en público, porque a su juicio el hombre que se va solo a un lugar solitario induce al otro a la tentación de ejercitarse ${ }^{59}$. No hay más que dos crímenes castigados con la muerte, y en este castigo es donde se observa mejor la locura de su sistema judicial ${ }^{60}$. Los hermanos y hermanas no pueden casarse entre sí sin incurrir en la pena de muerte, y nadie debe ejercer la magia sin permiso, pero los magos deben mostrar su habilidad delante de las autoridades y obtener la autorización correspondiente para ejercer su oficio ${ }^{61}$.

No obstante, la mención acertada de Waltari al rey hitita Suppiluliuma, ubicado cronológicamente en este período amarniense (alrededor de una veintena de años hacia la mitad del s.XIV a.C. $)^{62}$, nos lleva a recordar que fue uno de los per-

The Origin and History of Hebrew Law, Chicago 1931; KOROSEC, V. «Beiträge zum hethitischen Privatreicht», Zeitschrift der Savigny-Stiftung für Rechtsgeschichte 52 (1932), pp. 156 ss.; así como las ediciones posteriores de NEUFELD, E. The Hittite Laws, London 1951; FRIEDRICH, Die Hethitischen Gesetze, Leiden 1959; IMPARATI, F. Le leggi ittite, Roma 1964; KOROSEC, «Gesetze. B. Hatti», RIA 3 (1969), pp. 288 ss.; von SCHULER, E. «Hethitische Rechtsbücher», en Texte aus der Umwelt des Alten Testaments I: Rechtsbücher, Gütersloh 1982, pp. 96 ss.; HOFFNER ${ }^{\mathrm{j}}$, H. A., Laws; y las traducciones en

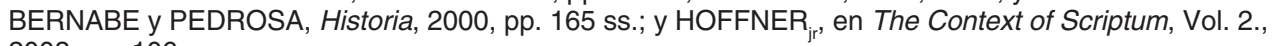
2003, pp. 106 ss.

56 Aunque las leyes hititas no son tan severas como algunas de las conservadas en el Oriente Próximo antiguo (SANMARTíN, J., Códigos legales de tradición babilónica, Madrid 1999), hay que establecer que sí hubo pena de muerte, aunque no en tantos casos como se podría esperar: hechicería, desobediencia a la autoridad de los hombres libres al rey u otros dignatarios, o de los siervos a sus amos, o bien prácticas de bestialismo (Leyes $§ \S 170,173 a-b, 187-188$ ), vid. HOFFNER, H. A., Laws, pp. 136,

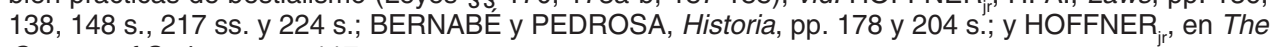
Context of Scriptum, pp. $117 \mathrm{~s}$.

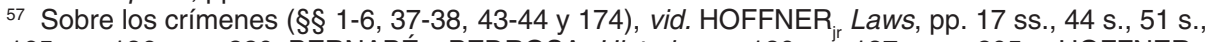
139, 165 ss., 186 ss. y 220; BERNABÉ y PEDROSA, Historia, pp. 180 ss., 187 ss., y 205; y HOFFNER jr$^{\text {, }}$ en The Context of Scriptum, pp. 107, 110 y 117.

58 Las leyes hititas no hablan de matrimonios estériles y las consiguientes anulaciones, algo que va con la idea de Waltari de que los hititas necesitaban tener muchos hijos buscando un aumento de la población. En cuanto a la normativa sobre algunos aspectos matrimoniales (§§ 26-36, 175), vid. HOFF-

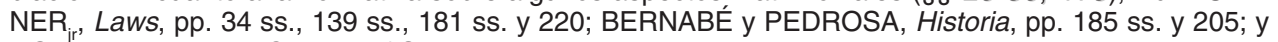
HOFFNER $_{\mathrm{ir}}$, en The Context of Scriptum, pp. 109 ss. y 117.

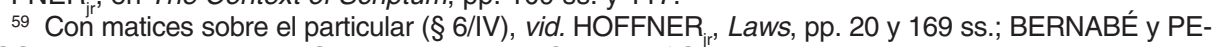
DROSA, Historia, p. 181; y HOFFNER ${ }_{\mathrm{j}}$, en The Context of Scriptum, p. 107.

60 Sobre la pena capital, vid. supra.

61 WALTARI, Sinuhé p. 277.

62 Datos sobre el monarca hitita Suppiluliuma (contemporáneo en los últimos años de los faraones Amen-Hotep III, Amen-Hotep IV-Akhenatón, Smenkhkare, Tutankhamón y acaso Ay), pudieron ser conocidos por Waltari de trabajos iniciales como GOETZE, A., «Šuppiluliumas syrische Feldzüge», Klio 19 (1924), pp. 347 ss.; FRIEDRICH, J., «Ein Bruchstück des Vertrages Mattiwaza-Shuppiluliuma in hethitischer Sprache?», AfO 2 (1924-25), pp. 119 ss.; CAVAIGNAC, E., Suppiluliuma et son temps, Paris 
Tradiciones literarias y tradiciones históricas en Sinuhé, el egipcio de Waltari...

sonajes más destacados de la historia hitita. Suppiluliuma, con un prolongado reinado, se convirtió en el verdadero fundador de un Imperio. Con él Hatti fue considerada una de las potencias más relevantes de la historia próximo oriental teniendo como principales rivales a los poderes más tradicionales y seculares del momento, como la Babilonia casita, Mitanni, la Asiria del Reino Medio o el Egipto de la Dinastía XVIII:

A mi llegada al país de Khatti, su gran rey Shubbiluliuma reinaba desde hacía veinticinco años y su nombre era tan temido que la gente se inclinaba y levantaba el brazo al oírlo, y lanzaba vítores en su honor, porque había restablecido el orden en el país y sometido numerosos pueblos. Habitaba un palacio de piedra en el centro de la ciudad y se contaban muchas leyendas sobre sus hazañas y sus altos hechos, como es el caso con todos los grandes reyes, pero no pude verlo, como tampoco los enviados de Mitanni que tuvieron que depositar sus regalos sobre el entarimado de la gran sala de recepción, y los soldados se mofaban de ellos y los insultaban ${ }^{63}$.

En cuanto a la práctica médica en el mundo hitita, si bien se ha conservado algo en su documentación, ésta pudo ser menos avanzadas que la de otras áreas del Oriente Próximo. En algún caso la corte hitita debió recurrir a médicos foráneos (egipcios, babilonios, e incluso del ámbito hurro-luvita de Kizzuwatna al SE de Anatolia $)^{64}$. Waltari, que siempre recalca el interés de Sinuhé por la medicina allí

1932; estudios posteriores a Sinuhé, como GÜTERBOCK, H. G., «Neue Texte zur Geschichte Šuppiluliumas», IF 60 (1950), pp. 199 ss.; GÜTERBOCK, «The Deeds of Suppiluliuma as Told by his Son, Mursili Il», JCS 10 (1956), pp. 41 ss., 75 ss. y 107 ss. (previamente, CAVAIGNAC, E., op. cit., 1931); GÜTERBOCK, «Mursili's accounts of Suppiluliuma's dealing with Egypt», RHA 66 (1960), pp. 57 ss.; KITCHEN, K. A., Suppiluliuma and the Amarna Pharaohs. A Study in Relative Chronology, Liverpool 1962 (cf. HOUWINK TEN CATE, Ph. H. J., BiOr 20 [1963], pp. 270 ss.); HOUWINK TEN CATE, «A New Fragment of the "Deeds of Suppiluliuma as Told by his Son, Mursili Il" », JNES 25 (1966), pp. 27 ss.; ASTOUR, M. C., «La Partition of the Mukiš-Nuhhaše-Nii by Suppiluliuma. A Study in Political Geography of the Amarna Age», Or 38 (1969), pp. 381 ss.; BRYCE, T. R., "Some Observations on the Chronology of Suppiluliuma's Reign», AnSt 39 (1989), pp. 19 ss.; FREU, J., «Les guerres syriennes de Suppiluliuma et la fin de l'Ere Amarnienne», Hethitica 11 (1992), pp. 39 ss.; KEMPINSKI, A., «Suppiluliuma I. The Early Years of His Career», en kinattutu ša darati. Raphael Kutscher Memorial Volume, Tel Aviv 1993, pp. 81 ss.; BECKMAN, G. M., «Some observations on the Šuppiluliuma-Šattiwazza Treaties (CTH 51-52)», en The Tablet and the Scroll. Near Eastern Studies in Honour of Willian W. Hallo, Bethesda, Maryland, 1993, pp. 53 ss.; CORNIL, «Le traité de Suppiluliuma et Shattiwaza», RIDA XLV (1998), pp. 13 ss.; FREU, «La Chronologie du règne de Suppilulima: Essai de mise au point», en Silva Anatolica. Anatolian Studies Presented to M. Popko on the Occasion of His 65 th Birthday. Warsaw 2002, pp. 87 ss.; PARKER, V., "Chronologie des Suppilulimas I», AoF 29/1 (2002), pp. 31 ss.; HOFFNER, r, H. A., «Deeds of Šuppiluliuma», en The Context of Scriptum, Vol. 1, 2003, pp. 185 ss.; y, muy recientemente, una vision del personaje y su contexto histórico en GONZÁLEZ SALAZAR, J. M., El Imperio hitita. Suppiluliuma, Cuenca 2010.

${ }^{63}$ WALTARI, Sinuhé pp. 277 s. Hay que establecer que las aventuras de Sinuhé se desarrollaron no sólo con Suppiluliuma sino bajo el breve reinado de su hijo Arnuwanda II y el inicio de su sucesor y hermano Mursili II (finales del s. XIV a.C.).

64 La medicina en la Antigüedad también tuvo un importante componente mágico-religioso, muchos rituales fueron empleados para intentar sanar a los enfermos. Sobre la medicina hitita, entre otros, GÜTERBOCK, H. G., «Hittite Medicine», Bulletin of the History of Medicine 36/2 (1962), pp. 109 ss.; BURDE, C., Hethitische medizinische Texte, Wiesbaden 1974; BECKMAN, G. M., «Medizin. B. Bei den Hethitern», RIA 7 (1990), pp. 629 ss.; BECKMAN, «From Cradle to Grave: Women's Role in Hittite Medicine and Magic», JAC 8 (1993), pp. 25 ss.; HAAS, V., Materia Magica et Medica Hethitica. Ein Beitrag zur Heilkunde im Alten Orient, Berlin-New York 2003; y, en general para la utilización de la magia en los proce- 
por donde pasa, y, siguiendo en sus descripciones con su línea de liberalidad literaria, tampoco muestra un panorama bueno:

No me pareció al principio que un médico debiese tener mucho trabajo en esta villa, porque, por lo que comprendí, los hititas se avergüenzan de las enfermedades y las ocultan cuanto pueden, y los niños débiles o contrahechos son matados en cuanto nacen, así como los esclavos enfermos. Sus médicos no me parecieron muy hábiles; son hombres incultos que no saben leer, pero tratan hábilmente las heridas y contusiones y tienen excelentes remedios contra el mal de las montañas y las fiebres. Sobre este punto yo me instruí con ellos. Pero si alguien caía mortalmente enfermo, prefería la muerte a la curación, por miedo a quedar enfermizo hasta el fin de sus días. En efecto, los hititas no temen a la muerte, como todos los pueblos civilizados, sino que temen más la debilidad del cuerpo.

Pero, al fin y al cabo, todas las grandes ciudades son parecidas, así como los nobles de todos los países. Así fue que cuando mi reputación se hubo extendido, numerosos hititas acudieron a mis cuidados y pude curarlos, pero acudían a verme disfrazados, a hurtadillas y de noche, para que no se les desconsiderara. Me hicieron regalos generosos, de manera que acabé acumulando mucho oro y plata en Khatushash, cuando había creído marchar como un mendigo. El gran mérito le corresponde a Kaptah, que, como de costumbre, pasaba el tiempo en tabernas y hosterías donde la gente se reunía, y contaba mis alabanzas y ensalzaba mi saber en todas las lenguas posibles, y así los servidores hablaban de mí a sus dueños ${ }^{65}$.

Uno de los aspectos más interesantes de la visita de Sinuhé a Hattusa es su conversación con el «epistológrafo» real. Su intención, siguiendo las recomendaciones de su amigo Horemheb, es conseguir toda la información posible de los lugares por donde viaja ${ }^{66}$, y es este alto personaje de la cancillería hitita quien, sin desvelar grandes secretos, le deja bien claro quiénes son los hititas y cuáles son sus intenciones con respecto a los poderes vecinos en un futuro próximo. El largo diálogo se establece en unos términos favorables para los intereses de cada parte, a pesar de la desconfianza mutua que subyace, las medias verdades y lo sorprendente de algunas afirmaciones:

Fui, sobre todo, informado por el epistológrafo real, que hablaba y escribía varias lenguas y se ocupaba de la correspondencia extranjera del rey y no estaba ligado por las costumbres ${ }^{67}$. Le di a entender que había sido expulsado de Egipto y

sos puramente médicos, GONZÁLEZ SALAZAR, J. M., Rituales hititas. Entre la magia y el culto, Madrid 2009, pp. 183 ss. (Rituales de Nacimiento) y 242 ss. (Ritual de Paskuwatti contra la impotencia sexual). 65 WALTARI, Sinuhé, p. 278.

66 Cuando está en Hattusa, con su comportamiento y su saber médico, Sinuhé es capaz de realizar sus propósitos indagando entre unos hititas desconfiados y remisos a dar información abiertamente: «Supe así ganar su amistad y pude hacerles muchas preguntas sobre temas que no me hubiera atrevido a abordar en público» (WALTARI, Sinuhé, p. 279).

67 Estaríamos hablando de uno de los principales cargos de la corte hitita, como unos de responsables de la actividad de la cancillería de Hatti, aunque sólo tenga que ver con la correspondencia oficial. Sobre la correspondencia real y el personal encargado, HOFFNER ${ }_{\mathrm{j} r}, \mathrm{H}$. A., Letters from the Hittite Kingdom, Atlanta 2009, pp. 7 ss. (cf. GONZÁLEZ SALAZAR, J. M., Suppiuliuma, pp. 95 ss.; en general, BRYCE, T. R., Letters of the Great Kings of Ancient Near East. The Royal Correspondence of the Late Bronze Age, London 2003). Para la importancia de la diplomacia hitita, vid. supra. 
Tradiciones literarias y tradiciones históricas en Sinuhé, el egipcio de Waltari...

que no podría volver allí nunca más, y que recorría los países para ganar oro y aumentar mi saber, y que mis viajes no tenían otro objeto. Por esto me concedió su confianza y respondió a mis preguntas cuando le ofrecí vino mientras hacía bailar a Minea delante de él. Así fue como le pregunté un día:

- ¿Por qué Khatushash está cerrada a los extranjeros y por qué las caravanas de mercaderes tienen que seguir determinadas rutas, cuando vuestro país es rico y vuestra villa rivaliza en curiosidades con cualquier otra? ¿No sería mejor que los otros pueblos pudiesen conocer vuestro poderío para elogiaros entre ellos como merecéis? ${ }^{68}$.

Saboreó el vino y, dirigiendo miradas de admiración a los flexibles miembros de Minea, dijo:

-Nuestro gran rey Shubbiluliuma dijo al subir al trono: «Dadme treinta años y haré del país de Khatti el imperio más poderoso que el mundo habrá visto jamás.» Este plazo está próximo a expirar y creo que pronto el mundo oirá hablar del país de los Khatti más de lo que en realidad quisiera.

-Pero -le dije yo- yo he visto en Babilonia sesenta veces sesenta veces sesenta soldados desfilar delante del rey y el ruido de sus pasos era como el estruendo del mar. Aquí no he visto más de diez veces diez soldados juntos y no comprendo qué hacéis de los numerosos carros de guerra que construís en vuestra villa, porque, ¿qué haréis de ellos en las montañas, puesto que están destinados a combatir en llano? ${ }^{69}$.

Se rió y dijo:

-Muy curioso eres por ser médico, Sinuhé el egipcio. Quizá sea para ganar nuestro mezquino pan vendiendo los carros a los reyes de la llanura. $Y$ al decir estas palabras me guiñaba el ojo y adoptó un aire malicioso.

-No creo una palabra de lo que me dices -le dije osadamente-. Antes prestaría el lobo sus garras y sus dientes a la liebre; si os conozco bien. Se echó a reír ruidosamente golpeándose los muslos, después bebió un sorbo y dijo:

-Voy a contárselo al rey y acaso veas una gran caza de liebres, porque el derecho de los hititas es diferente del de las llanuras. Si no os comprendo mal, en vuestro país los ricos gobiernan a los pobres, pero en el nuestro los fuertes gobiernan a los débiles, y creo que el mundo conocerá la nueva doctrina antes de que tus cabellos hayan blanqueado, Sinuhé ${ }^{70}$.

-El nuevo faraón de Egipto ha descubierto también un nuevo dios - dije yo, afectando candidez.

- Lo sé -dijo-, porque leo todas las cartas de mi rey, y este nuevo dios quiere la paz y dice que no hay conflicto en el mundo que no se pueda solventar amistosamente, y no tenemos nada contra este dios, al contrario, lo apreciamos mucho

68 No está tan claro que los hititas no permitiesen el acceso a Hattusa, y a pesar de existir un control estricto de las vías de comunicación para fines comerciales y militares, estás no debieron de estar cerradas al tráfico.

69 En este caso, parece más una provocación de Sinuhé hacia el canciller para conseguir una información fidedigna sobre el ejército hitita (en cuanto a su número y sus tácticas).

70 Ésta y otra serie de afirmaciones explícitas durante este diálogo deja muy a las claras lo que realmente está detrás del comportamiento de los hititas: su ambición desmesurada de conquista y de imposición de un dominio sobre los demás por medio de la fuerza. 
mientras reine en Egipto y los llanos. Vuestro faraón ha enviado a nuestro rey una cruz egipcia que llama signo de vida, y gozará, ciertamente, de la paz durante algunos años todavía, si nos manda suficiente oro para que podamos almacenar más cobre y hierro y cereales y fundar nuevos talleres y preparar carros de guerra más pesados todavía; porque todo esto exige mucho, y nuestro rey ha traído a Khatushash los más hábiles armeros de todos los países, ofreciéndoles salarios generosos, pero no creo que el saber de un médico pueda responderte a la pregunta de por qué lo ha hecho.

-El porvenir que predices alegrará a los cuervos y los chacales -le dije-, pero a mí no me causa la menor alegría ni veo en él nada agradable. He observado que las muelas de vuestros molinos son movidas por esclavos con los ojos arrancados y en Mitanni se cuentan de vuestras crueldades en las regiones fronterizas historias que no quiero repetirte para no ofuscarte, porque son intolerables para un pueblo civilizado.

- ¿Qué es civilización? -preguntó, sirviéndose vino-. También nosotros sabemos leer y escribir y conservamos en nuestros archivos las tablillas de arcilla numeradas $^{71}$. Por pura filantropía arrancamos los ojos a los esclavos condenados a empujar las muelas de los molinos, porque es un trabajo muy penoso y les parecería más penoso aún si viesen el cielo y la tierra y los pájaros en el aire. Esto les daría vanas ideas y habría que condenarlos a muerte por sus tentativas de evasión. Si en nuestras fronteras los soldados cortan las manos de unos y sobre los ojos de otros

71 Posteriormente, una embajada hitita en Egipto, al justificar algunos aspectos de su ferocidad y barbarie, afirma: «-Sabemos que se cuentan muchas leyendas atroces sobre nuestro país, pero es obra de pérfidos envidiosos. Por esto somos felices al demostraros que somos gente culta que sabe leer y escribir. No comemos carne cruda ni bebemos la sangre de los niños, como se cuenta, sino que apreciamos la cocina siria y la egipcia. Somos gente apacible que detestamos las querellas y a cambio de nuestros regalos sólo os pediremos algunas informaciones que puedan sernos útiles para desarrollar el nivel cultural de nuestro pueblo» (WALTARI, Sinuhé p. 563). Sobre los archivos de textos cuneiformes de la capital hitita, en particular en la acrópolis del Büyükkale, vid. LAROCHE, E., «La Bibliothèque de Hattusa», ArOr 17 (1949), pp. 7 ss.; BITTEL, K., op. cit., 1970, pp. 14 ss. y 84 ss. (rev. 1983, pp. 22 ss. y 110 s.); OTTEN, H., «Archive und Bibliotheken in Hattusa», en Cuneiform Archives and Libraries. Leiden 1986, pp. 184 ss.; KOŠAK, S., «The Palace Library «Building A» on Büyükkale», en Studies Presented to p. H. J. Houwink Ten Cate, 1995, pp. 173 ss.; ALAURA, S., «Archive und Bibliotheken in Hattusa», en Akten des IV. Internationalen Kongresses für Hethitologie, Würzburg, 4.-8. Oktober 1999, Wiesbaden 2001, pp. 12 ss. También se han hallado textos en otros sectores de la capital hitita, como en la Ciudad Baja (en el Gran Templo o Templo I, o la «Casa de la Pendiente»), pero la dificultad se plantea a la hora de establecer las correspondencias entre los textos y los lugares donde se han encontrado, y el significado de muchos de estos puntos de almacenamiento de tablillas como archivos o bibliotecas, vid. HOFFNER $_{\mathrm{ir}}$, H. A., «History and Historians of the Ancient Near East: the Hittites», Or 49 (1980), pp. 286 s. y 323 ss. (cf. CORNIL, «Textes de Boghazköy. Liste des lieux de trouvaille», Hethitica 7 [1987], pp. 5 ss.). Por lo común, los archivos de la capital hitita muestran en sus textos una gran riqueza temática. Una primera estructuración la proporciona Laroche en su Catálogo (Catalogue des textes hittites [CTH], Paris 1971, con sus suplementos en RHA 30 y 32 [1972 y 1975], pp. 94 ss. y 61 ss.; también MARAZZI, M., «ll corpus dei testi cuneiformi ittiti: vecchi e nuovi strumenti di lavoro», QuadUrbCCI 18 [1984], pp. 173 ss.) con documentos históricos de variados períodos y géneros, textos administrativos y técnicos, jurídicos, mitológicos (anatólicos y extranjeros), himnos y plegarias, rituales, administración religiosa, adivinación, fiestas y cultos, en lenguas extranjeras (como el hático de la población prehitita; o las de la familia indoeuropea: palaíta y luvita; o la aglutinante extra-anatólica, el hurrita, además de literatura sumerio-acadia), y varia (GÜTERBOCK, H. G., «Die Historische Tradition und ihre Gestaltung bei Baby-

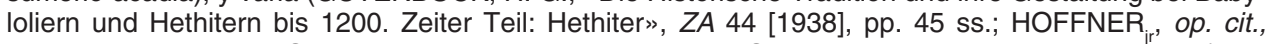
1980, pp. 283 ss.; HAAS, V., Die hethitische Literatur. Texte, Stilistik, Motive, Berlin-New York. 2006). En general, sobre los archivos en el Oriente Próximo, PEDERSÉN, O., Archives and Libraries in the Ancient Near East 1500-300 B.C. Bethesda, Maryland 1998. 
Tradiciones literarias y tradiciones históricas en Sinuhé, el egipcio de Waltari...

dan la vuelta a la piel del cráneo, no es por crueldad, porque has podido observar que somos hospitalarios y amables, adoramos a los niños y a los animalitos y no apaleamos a las mujeres ${ }^{72}$. Pero nuestro objeto es despertar el miedo y el terror en los pueblos hostiles a fin de que a la larga se sometan a nuestro poderío sin luchar, evitándose de esta forma daños y destrucciones. Porque no nos gustan los destrozos y desperfectos, y deseamos encontrar los países tan intactos como sea posible y las ciudades respetadas. Un enemigo que tiene miedo está vencido a medias.

- ¿Todos los pueblos son, pues, vuestros enemigos? -le pregunté yo, irónicamente-. ¿No tenéis, según he de suponer, ningún amigo?

-Nuestros amigos son los pueblos que se someten a nuestro poderío y nos pagan un tributo -dijo con tono doctoral-. Los dejamos vivir a su antojo y no herimos ni sus tradiciones ni sus dioses, con tal de que podamos gobernarlos. Nuestros amigos son también, en general, los pueblos que no son vecinos, en todo caso hasta el momento en que llegan a serlo, porque entonces observamos en ellos muchos rasgos irritantes que perturban la buena comprensión y nos fuerzan a declararles la guerra. Este fue el caso hasta ahora, y temo que así será en el porvenir, si conozco bien a nuestro gran rey.

72 Es un tema recurrente la crueldad de los hititas en la novela de Waltari, como cuando Sinuhé está en el campamento del rey sirio Aziru (vid. infra): «(...) dos oficiales hititas torturan a las mujeres porque es su costumbre» (WALTARI, Sinuhé p. 526); bien la acción del propio Sinuhé: “Compré también algunas mujeres, pero a otras les di una poción para hacerlas morir, porque después de las violencias de los hititas la muerte era para ellas una liberación» (WALTARI, Sinuhé p. 529). Éstos y otros ejemplos que pueblan el texto sobre la brutalidad hitita puede chocar con la realidad histórica, puesto que no fueron uno de los pueblos más feroces que ha conocido el Próximo Oriente antiguo (vid. ARCHI, A., «L'humanité des Hittites», en Florilegium Anatolicum: Mélanges offert à Emmanuel Laroche, Paris 1979, pp. 37 ss.; cf. GONZÁLEZ SALAZAR, J. M., et al., «Los asirios en el Antiguo Testamento», en IV Simposium Bíblico Español-I Ibero-americano: «Biblia y Culturas», Valencia-Granada 1993, pp. 181 ss.). Los propios egipcios presentados por Waltari, sobre todo en el período más álgido del reinado de Akhenatón, en plena semiguerra civil, se los podría considerar de extremadamente violentos. Un ejemplo, tras la muerte de Akhenatón, se observa en los sacrificios humanos realizados ante Horemheb en un templo por su triunfo ante los hititas: «-Por Seth y todos los demonios, nunca hubiera creído que los sacerdotes de Sekhmet hiciesen todavía sacrificios humanos. Pero estaban por lo visto llenos de celo, porque las puertas de su templo no se habían abierto desde hacía más de cuarenta años. Ahora comprendo por qué me han pedido prisioneros hititas y sirios para sus ceremonias» (WALTARI, Sinuhé, p. 608). Con Sinuhé describiendo la actuación del ejército de Horemheb en campaña contra los hititas: «Atravesando el desierto a marchas forzadas, bajo el polvo y el calor, siguiendo las trazas de Horemheb, el ejército que yo acompañaba no veía sino de vez en cuando el cuerpo medio devorado de un soldado caído del carro (...) y los cadáveres de los hititas desnudos y empalados en señal de victoria» (WALTARI, Sinuhé, p. 619). También: "A cada soldado de Ghaza Horemheb le dio una cadena de oro (...). Les dio también mujeres sirias, pero (...) comenzaron a torturarlas a la manera hitita, porque durante el sitio habían aprendido muchas nuevas costumbres, como, por ejemplo, desollar vivos a los prisioneros y colgar las pieles en los muros» (WALTARI, Sinuhé, pp. 639 ss.). Más desmanes de las tropas de Horemheb: «En verdad fue en Joppe [Palestina] donde vi hasta qué punto el hombre es el lobo del hombre, porque no hubo crimen ni infamia que allí no fuese llevada a cabo durante aquellos días de saqueo e incendio. Los soldados ebrios incendiaban las casas para divertirse, a fin de ver por la noche mientras robaban y saqueaban, abusaban de las mujeres y torturaban a los comerciantes para obligarles a revelar sus escondrijos. Algunos se apostaban en una esquina y asesinaban al primer sirio que pasase, fuese hombre o mujer, anciano o niño. Mi corazón se endurecía al ver el espectáculo de la maldad del hombre (...)» (WALTARI, Sinuhé p. 652). O incluso: «Horemheb, muy contrariado, tuvo que arrojar al río los cuerpos de los jefes hititas y sirios que había hecho colgar cabeza abajo en la popa del navío, a la manera de los grandes faraones de antaño" (WALTARI, Sinuhé, p. 667). No hay lugar a dudas sobre la inflada visión de la violencia gratuita de los hititas que da Waltari a lo largo de la novela, que tendría que ver con su particular presentación del reino de Hatti como Estado violento. Sin embargo, no deja de mostrar una igual o mayor violencia entre los sirios o los propios egipcios. 
- ¿Y vuestros dioses no tienen nada que objetar? Porque en los demás países suelen decidir sobre lo justo y lo falso.

- ¿Qué es lo justo y qué es lo falso? -preguntó a su vez-. Para nosotros es justo lo que deseamos y falso lo que desean nuestros vecinos. Es una doctrina muy simple que hace la vida fácil y la diplomacia cómoda, y no difiere gran cosa, a mi modo de ver, de la teología de los llanos, porque, por lo que he entendido, los dioses de los llanos estiman justo lo que desean los ricos y falso lo que desean los pobres. Pero si quieres realmente informarte respecto a nuestros dioses, debes saber que nuestros dioses son el Cielo y la Tierra, y los honramos cada primavera, cuando la primera lluvia del cielo fertiliza la tierra como la simiente del hombre fertiliza a la mujer ${ }^{73}$. Durante estas fiestas relajamos un poco la austeridad de nuestras costumbres, porque el pueblo tiene que poder desahogarse por lo menos una vez al año. Por eso entonces se engendran muchos hijos, lo cual es conveniente, porque un país crece a causa de los niños y los matrimonios precoces. El pueblo posee, naturalmente, un gran número de dioses menores, como todos los pueblos, pero no hay que tenerlos en cuenta, porque no tienen importancia política. En estas condiciones no creo que puedas negar a nuestra religión una cierta grandeza, si es que puedo expresarme así. cido.

-Cuanto más oigo hablar de los dioses, más asco me dan -dije yo, desfalle-

El epistológrafo se limitó a echarse a reír, recostándose en su asiento, con la nariz ya rubicunda.

-Si eres cuerdo y previsor -prosiguió-, te quedarás con nosotros y honrarás a nuestros dioses, porque todos los demás pueblos han dominado a su vez el mundo conocido y ahora nos toca a nosotros. Nuestros dioses son muy poderosos y sus nombres son Poder y Miedo, y vamos a elevarles grandes altares con cráneos blanqueados. Si eres lo suficientemente tonto para abandonarnos, no te prohíbo que repitas mis palabras, porque nadie te creerá, ya que todo el mundo sabe que los hititas son unos pobres pastores que no practican más que el pastoreo y viven en las montañas con sus cabras y corderos. Pero me he demorado ya demasiado en tu casa y debo ir a vigilar a mis escribas e imprimir las monedas sobre arcilla tierna para asegurar a todos los pueblos nuestras buenas intenciones, tal como corresponde a las funciones que desempeño ${ }^{74}$.

Con lo que ha «sonsacado» al canciller hitita, que realmente ha sido lo que éste le ha querido contar, parece tener suficiente información de primera mano, que, por su contenido, deja bien a las claras las intenciones del reino de Hatti para con sus vecinos:

Se marchó [= el «epistológrafo»] y aquella misma noche le dije a Minea:

73 Junto a las divinidades Solares del Cielo y de la Tierra, el dios de la Tempestad fue de las principales divinidades que encabezaron el panteón hitita. En él se fueron integrando a otros dioses hasta formar un extenso panteón en el que todas las divinidades tuvieron un destacado papel (SINGER, I., op. cit., 1994, pp. 81 ss.; o KARASU, C., op. cit., 2003, pp. 221 ss.). Por otra parte, la principal fiesta de la primavera fue la del EZEN ${ }_{4}$ AN.TAH.ŠUM ${ }^{S A R}$, pero no fue la única oficial, p. ej., en el otoño hubo otra con la misma importancia, la del nuntarriyasha, siguiendo un complejo calendario litúrgico, GONZÁLEZ SALAZAR, J. M., Rituales hititas, pp. 45 ss. y 121 ss.

74 WALTARI, Sinuhé, pp. 279 ss. 
Tradiciones literarias y tradiciones históricas en Sinuhé, el egipcio de Waltari...

- Sé ya lo suficiente sobre el país de los Khatti y he encontrado lo que quería. Por eso estoy dispuesto a abandonar contigo este país, si los dioses lo permiten, porque aquí todo apesta a cadáver y un olor de muerte se me agarra a la garganta. Verdaderamente, la muerte planeará sobre mí como una sombra pesada mientras estemos aquí, y no dudo de que el rey me haría empalar si supiese de cuántas cosas me he enterado. Porque cuando quieren matar a alguien, no lo cuelgan de las murallas como en los pueblos civilizados, sino que los empalan. Por esto, mientras esté en el interior de estas fronteras, estaré inquieto. Después de todo lo que he oído decir preferiría haber nacido cuervo.

Gracias a mis enfermos influyentes obtuve un salvoconducto que me autorizaba a tomar un barco para salir del país, pese a que mis clientes lamentasen profundamente mi marcha, insistiendo en que me quedase y asegurándome que en pocos años acumularía una fortuna. Pero nadie se opuso a mi marcha, y yo sonreía y les contaba historias que les gustaban, de manera que nos separamos en buena amistad llevándonos ricos regalos. Así nos alejamos de las horribles murallas de Khatushash, detrás de las cuales se preparaba el mundo futuro $(\ldots)^{75}$.

Es realmente llamativa a poco que se analice este diálogo, y teniendo presente que la novela presenta un contexto histórico con distintos Estados (grandes y pequeños) en un precario equilibrio, la comparación de lo que expresa con momentos caracterizados por un auténtica paz armada, que nos trae a la mente situaciones vividas por el propio Waltari y vinculadas a nuestra historia europea contemporánea. En la novela hay un Estado, el reino hitita de Hatti, que busca imponerse a los demás, pensando en implantar su dominio político y territorial a través de la diplomacia y, en particular, por las armas, el terror y la crueldad. ¿A qué nos recuerda? El tiempo que le tocó vivir a Waltari ${ }^{76}$ antes de escribir Sinuhé fue muy similar, casi análogo, con una Europa de entreguerras plagada de Estados en crisis, preludio de una gran conflagración mundial. Esa angustia latente ante lo que parece surgir en Europa con fuerza y su pesimismo sobre los acontecimientos venideros se refleja casi fielmente en su libro, con un punto de inflexión en este diálogo entre Sinuhé y el escriba-canciller hitita ${ }^{77}$. Es aquí dónde podríamos afirmar que Waltari, usando a su manera el recurso del paralelismo histórico pero a la inversa (del presente hacia el pasado), podría haber convertido a la potencia emergente del reino hitita en la imagen proyectada de la Alemania nazi, o al menos de un arquetípico estado totalitario militarizado con ansias de expansión a costa de todo y de todos.

75 WALTARI, Sinuhé, p. 283.

76 Concretamente Finlandia en esos momentos tuvo que someterse a los vaivenes que le imponían las potencias del entorno, fuese la URSS de Stalin o la Alemania nazi.

77 Las aseveraciones de este último, como se ha visto en el texto, son representativas del papel que asigna Waltari a los hititas en la trama. A ellas habría que sumar la descripción del saludo que recibía el propio Suppiluliuma de sus súbditos: “(...) la gente se inclinaba y levantaba el brazo al oírlo, y lanzaba vítores en su honor (...)» (vid. supra). Lo expresado por el, hasta cierto punto, asustado Sinuhé es la replica pesimista de quién ve lo que puede avecinarse en el futuro: «-El porvenir que predices alegrará a los cuervos y los chacales -le dije-, pero a mí no me causa la menor alegría ni veo en él nada agradable». Se siente hastiado y no le hace falta indagar más: «-Sé ya lo suficiente sobre el país de los Khatti y he encontrado lo que quería. (...) porque aquí todo apesta a cadáver y un olor de muerte se me agarra a la garganta». 
2.3. El siguiente bloque sobre los hititas presenta referencias más dispersas porque es el momento en el que Sinuhé ya ha abandonado el territorio hitita y tiene que informar a Horemheb. A pesar de ello se mantiene la relevancia de las citaciones puesto que es el reflejo de una amenaza que proviene de más allá de las fronteras de Egipto. En el período amarniense, con Akhenaton ${ }^{78}$, la situación en Siria empezaba a ser complicada para los intereses egipcios, sobre todo por los movimientos de aliados como Aziru de Amurru, antiguo «conocido» de Sinuhéc ${ }^{79}$, y la participación del reino de Hatti. Por tanto, Egipto está viviendo un período de falsa tranquilidad en el exterior, con unos «enemigos» muy activos ${ }^{80}$.

Lo que empieza a preocupar a Sinuhé es proporcionar la información que ha recavado sobre los hititas en su viaje a Hatti. Todavía se encuentra en Siria y comprueba que la disposición con respecto a los egipcios empeora con una conflictividad latente ${ }^{81}$. Incluso, antes de regresar a Egipto y ponerse en contacto con Horemheb, llega a conversar con un ambicioso Aziru, que fomenta el odio contra los egipcios respaldado por Hatti. Lo que se avecina para Egipto en la región es muy perjudicial, aunque Sinuhé intenta que Aziru no se envalentone:

Su cuarto de trabajo estaba en efecto lleno de tablillas de arcilla, y los mensajeros le llevaban cartas de todos los rincones de Siria. Recibía también mensajes de los reyes hititas y de Babilonia, pero no me permitió leerlas, lo cual no le impidió jactarse de ellas. Me interrogó sobre el país de los hititas y Khatushash, pero comprobé que sabía tanto como yo. Los enviados hititas iban a verle y conversaban con sus jefes y sus soldados y, viendo todo aquello, le dije:

-El león y el chacal pueden perfectamente entenderse para cazar a medias, pero, ¿has visto alguna vez al chacal recibir los mejores pedazos del botín? ${ }^{82}$

78 Para la compleja figura de este faraón, REDFORD, D., Akhenaten. The Heretic King, Princeton 1984; ALDRED, C., Akhenaten. King of Egypt, Londres 1988; cf. EATON-KRAUSS, M., «Akhenaten versus Akhenaten», BiOr 47 (1990), p. 541.

${ }_{79}$ El papel de Aziru, rey de Amurru (uno de los Estados sirios más importantes del período), en las intrigas y conflictos regionales de la época amarniense, se ha visto reflejado en las fuentes egipcias e hititas, vid. KLENGEL, H. «Aziru von Amurru und seine Rolle in der Geschichte der Amarnazeit», MIO 10 (1964), pp. 57 ss.; o LIVERANI, M., «Aziru, servitore di due padroni», en Studi orientalistici in ricordo di Franco Pintore, Pavia 1983, pp. 93 ss. Sobre el papel de Amurru, SINGER, I., «A Concise History of Amurru», en Amurru Akkadian: A Linguistic Study, Vol. II, Atlanta 1991a, pp. 134 ss.; SINGER, "The 'Land of Amurru' and the 'Lands of Amurru' in the Saušgamuwa Treaty», Iraq 53 (1991b), pp. 69 ss.; IZRE'EL, S., «Hatti and the Kingdom of Amurru: Linguistic Influences», y SINGER, «Hittite Cultural Influence in the Kingdom of Amurru», ambos en La circulation des biens, des personnes et des idées dans le Proche-Orient ancien. Actes de la XXXVIIle Rencontre Assyriologique Internationale (Paris, 8-10 juillet 1991), Paris 1992, pp. 227 ss. y 231 ss. Respect.; MILLER, J. L., «The Rebellion of Hatti's Syrian Vassals and Egypt's Meddling in Amurru», en Acts of the VIth International Congress of Hittitology, September 6 , 2005, Rome 2008, pp. 533 ss.

80 Aunque gran parte del reinado de Amen-Hotep IV-Akhenatón no se puede considerar totalmente dentro de lo tradicionalmente egipcio, bien es verdad que tampoco puede ser caracterizado de pacifismo religioso, vid. PÉREZ LARGACHA, A., «Akhenatón, ¿pacifismo religioso?, Espacio, tiempo y forma. Serie II, Historia Antigua 7 (1994), pp. 363 ss.

81 «(...) no me encontraba a gusto en Simyra y comencé a entrar en posesión de mis créditos y a preparar mi marcha, porque según mi promesa debía presentar mi informe a Horemheb. Tenía que regresar a Egipto» (WALTARI, Sinuhé, p. 334).

82 WALTARI, Sinuhé, p. 345. 
Tradiciones literarias y tradiciones históricas en Sinuhé, el egipcio de Waltari...

Una vez en Egipto, con los cambios que Akhenatón está llevando a cabo (p. ej., la construcción de la nueva capital en El-Amarna), Sinuhé informa brevemente a Horemheb ${ }^{83}$. Incluso cuando la rebelión de Aziru en Siria se hace más evidente, hay nuevos contactos de Sinuhé con Horemheb sobre los hititas:

Durante su estancia en la Ciudad del Horizonte [=El-Amarna] tuve tiempo suficiente para exponerle cuanto había visto y aprendido en el país de los khatti y en Creta. Me escuchó en silencio, moviendo a veces la cabeza como si estuviese ya al corriente de lo que le contaba, manejando el puñal que me había dado el capitán hitita del Puerto. Algunas veces me hacía preguntas infantiles como, por ejemplo: «¿Los soldados de Babilonia echan a andar con el pie izquierdo como los egipcios o con el derecho como los hititas?» O bien: «¿Los hititas llevan el caballo de reserva de los carros pesados de guerra al lado de los otros caballos o detrás del carro? -O aún: ¿Cuántos radios tienen las ruedas de los carros hititas, y van reforzados con metal?

Me hacía estas preguntas infantiles porque era soldado y los soldados se interesan por estas cosas sin importancia, como los chiquillos se divierten contando las patas de los ciempiés. Pero me hizo marcar por escrito todo lo que le dije respecto a las rutas, puentes y ríos, y también todos los nombres que le cité $(\ldots)^{84}$.

Sin embargo, hay una acuciante necesidad de ayuda por parte de los aliados sirios que parece encontrar oídos sordos en el faraón:

Los mensajes de Siria eran cada vez más angustiosos y a la llegada de cada correo me iba a los archivos para leer las tablillas conteniendo llamamientos desgarradores. Me parecía oír silbar las flechas en mis oídos y oler el humo de los incendios, y bajo las palabras respetuosas me parecía percibir los aullidos de los hombres moribundos y los gritos de los chiquillos destrozados, porque los amorritas eran salvajes y crueles y guerreaban bajo las órdenes de oficiales hititas, de manera que a la larga ninguna guarnición podía resistírseles ${ }^{85}$.

La caída de algunos lugares de la región sirio-palestina hace que sus vecinos se sometan a los enemigos de Egipto por temor a las consecuencias de resistir$\mathrm{se}^{86}$. Así, aunque el panorama que le plantea Horemheb a Akhenatón pueda ser desolador, puesto que la rebelión en Siria puede provocar que el siguiente paso sea la ocupación del Sinaí y después de los territorios del Bajo Egipto, éste no parece reaccionar ${ }^{87}$. Y cuando llega la respuesta del faraón es bajo la manera que se puede esperar de él:

83 «Traté de exponer a Horemheb lo que había observado por mi cuenta en Babilonia, en el país de los Khatti y en Creta» (WALTARI, Sinuhé p. 390).

${ }^{84}$ WALTARI, Sinuhé, pp. 428 ss.

85 WALTARI, Sinuhé, pp. 441 ss.

86 «Después de la caída de Jerusalén, las últimas villas fieles a Egipto renunciaron a la lucha y se aliaron a Aziru. (...) El rey Aziru mandó, en efecto, confeccionar con su cráneo [=del Príncipe de Jerusalén] una bella copa dorada que mandó al rey Shubbiluliuma de Khatushash, según me han dicho mis espías» (WALTARI, Sinuhé, p. 442).

${ }^{87}$ Como expresa con amargura Horemheb: «Pero si no temes a Siria, teme por lo menos a los hititas, porque su ambición no tiene límites» (WALTARI, Sinuhé, p. 443). 
- Jamás un enemigo ha hollado el suelo de Egipto, ni nadie osará hollarlo, porque Egipto es el país más rico y más poderoso del mundo. Pero para calmarte, puesto que tienes pesadillas, puedo decirte que los hititas son un pueblo bárbaro que apacienta sus rebaños en sus pobres montañas y nuestros aliados de Mitanni forman un baluarte contra ellos. He mandado también al rey Shubbiluliuma una Cruz de vida, y a su demanda le he dado también oro para que pueda colocar en sus templos una estatua mía de tamaño natural. Por esto no inquietará a Egipto, porque de mi recibe oro cada vez que lo reclama, pese a que el pueblo se queja de los impuestos que tengo que recaudar ${ }^{88}$.

Las alusiones a lo que acontece en Siria son cada vez más numerosas y cruentas $^{89}$. Sólo queda desplegar la diplomacia para evitar males mayores y aplazar lo evidente: los territorios sirio-palestinos fieles al faraón van cayendo y los aliados de Egipto no pueden ya mantenerse. Los hititas aprovechan para atacar Mitanni que había sido un poderoso aliado egipcio. Así, el enviado para hablar y negociar la paz con Aziru es el propio Sinuhé que actúa como mensajero y embajador según los usos diplomáticos de la época, viajando a través de unos territorios en guerra en los que le puede pasar de todo por ser egipcio ${ }^{90}$. Las negociaciones

88 WALTARI, Sinuhé, p. 444.

89 El propio Horemheb intenta por todos los medios que el faraón deje de lado su sentimiento de pacifismo universal y trae a las víctimas sirias para que se dirijan a Akhenatón aumentando lo que cuentan: «Horemheb había enviado a Menfis a una banda de fugitivos de Siria, con todo el esplendor de su miseria, para hablar al faraón, y creo que les había recomendado exagerar todavía más sus sufrimientos, de manera que su llegada causó sensación (...) - Escucha de nuestras bocas torturadas los gritos de dolor de los pueblos (...). Y levantaban los muñones de los brazos amputados hacia la terraza del faraón y decían: - iMira nuestros brazos, faraón Akhenaton! ¿Dónde están nuestras manos? Hicieron avanzar hombres con los ojos vaciados y ancianos con la lengua cortada que lanzaban aullidos enormes. $Y$ añadieron: - No nos preguntes dónde están nuestras mujeres y nuestras hijas, porque su destino es peor que la muerte entre las manos de los soldados de Aziru y de los hititas. Nos han vaciado los ojos y cortado las manos porque tenemos confianza en ti, faraón Akhenaton » (WALTARI, Sinuhé, pp. 507 ss.).

${ }_{90}$ El propio Horemheb le expone a Sinuhé algo que no le consuela: «(...) los hititas han atacado por fin Mitanni con todas sus fuerzas y han aniquilado su pueblo, de manera que este país no existe ya. Pero sus lanzas y sus carros están detenidos en Mitanni, y Babilonia se inquieta y equipa sus tropas para proteger sus fronteras, y los hititas no tienen tiempo de ayudar a Aziru. Es probable que Aziru, ahora que los hititas han conquistado Mitanni, comience a temerlos, porque no hay más protección entre su país y Siria. Por esto la paz que vas a ofrecer ahora a Aziru es el don más precioso" (WALTARI, Sinuhé, pp. 516). No obstante: «Horemheb tenía razón; en aquellos momentos la paz era más ventajosa para Aziru que para Egipto (...). Todo dependía de saber si los hititas, una vez su poderío consolidado en Mitanni, atacarían a Babilonia o, a través de Siria, a Egipto. El buen sentido decía que llevarían su esfuerzo sobre el punto de menor resistencia y Babilonia se armaba ya, mientras Egipto era más débil y no tenía armas. El país de Khatti era ciertamente un aliado desagradable, pero al entenderse con los hititas, Aziru se aseguraba una aportación de fuerzas, mientras al aliarse con Egipto contra los hititas, iba a un desastre cierto, puesto que bajo el reinado de Akhenaton, Egipto no tenía nada que ofrecerle» (WALTARI, Sinuhé p. 518). Más adelante, una embajada hitita en El-Amarna justifica la invasión de Mitanni: «podéis comprender que nuestro país es demasiado pequeño para nosotros, porque tenemos muchos hijos, ya que nuestro gran rey Shubbiluliuma los ama enormemente. Y necesitamos espacio para ellos y para apacentar nuestros ganados, y en Mitanni había sitio para nosotros, porque las mujeres no tienen más que uno o dos chiquillos. Por otra parte, no podíamos soportar ver reinar en este país la injusticia y la opresión, y en realidad los habitantes de Mitanni nos han llamado en su ayuda y hemos entrado en su país como liberadores y no como invasores. Ahora tenemos en Mitanni suficiente espacio vital para nosotros y nuestros hijos y nuestros ganados, y no soñamos con nuevas conquistas, porque somos un pueblo apacible y pacífico» (WALTARI, Sinuhé pp. 563 ss.). Al final, tras alabar Egipto, parecen convencer a todos menos a Sinuhé: «-Egipto es un país maravilloso y lo admiramos. Pero id también al nuestro, y 
Tradiciones literarias y tradiciones históricas en Sinuhé, el egipcio de Waltari...

traen una paz ratificada en una tablilla que tiene visos de ser más ficticia que real porque Aziru no parece dejar al margen las ventajas de su alianza con Hatti ${ }^{11}$. A pesar de ello, los intercambios de embajadas están a la orden del día y los propios hititas envían ante Akhenatón a sus delegados, si bien buscando abiertamente, con todo cinismo, cualquier información que puedan recibir.

Y he aquí que una embajada hitita llegó a la Ciudad del Horizonte, presidida por numerosos nobles, diciendo que iban a confirmar la amistad tradicional entre Egipto y el país de Khatti y a familiarizarse, además, con las costumbres egipcias de las cuales habían oído decir mucho bien y con el Ejército egipcio, cuya disciplina y armamento no dejaría de procurarles algunas informaciones útiles. Su actitud era deferente y cortés y eran portadores de numerosos regalos para los personajes de la Corte ${ }^{92}$.

2.4. La guerra abierta contra los hititas protagoniza una de las últimas partes de la novela. Horemheb al mando de tropas egipcias guerrea durante una serie de años acompañado de Sinuhé, que se convierte en un testigo directo, como «corresponsal de guerra» (igual que pudo ser Waltari como periodista en su complicada época). La sucesión al trono, con los reinados sucesivos de Smenkhkare, Tutankhamón, Ay y Horemheb ${ }^{93}$, recolocó, sobremanera, los aspectos tradicionales tras la «herejía» amarniense de Akhenatón ${ }^{94}$. Waltari proporciona bastante infor-

aprenderéis a conocer mejor nuestras costumbres. Gracias a estos halagos consiguieron ganar el favor general y la Corte y nada les quedó oculto. Yo pensaba en su país árido y en sus hechiceros empalados a lo largo de los caminos y me decía que su estancia en Egipto no presagiaba nada bueno para nosotros. $Y$ así estuve encantado de verlos marchar» (WALTARI, Sinuhé p. 564). En este punto, hay aspectos que se pueden señalar que tienen reminiscencias con las circunstancias contemporáneas de Waltari, como, p. ej., el de la necesidad de espacio, como la búsqueda del Lebensraum de la Alemania nazi.

91 «Estas condiciones fueron consignadas en unas tablillas de arcilla como un tratado de paz perpetuo entre Siria y Egipto y fue puesto bajo la protección de todos los dioses de Egipto y todos los de Siria, sin olvidar a Atón (...). Pero tanto Aziru como yo sabíamos que el tratado firmado para durar eternamente no valía siquiera la arcilla en que estaba escrito (...). En resumen, todo dependía de lo que harían los hititas a partir de Mitannì (WALTARI, Sinuhé p. 529 s.). El temor a los hititas también viene del embajador de Babilonia con el que se junta en Menfis a su vuelta de sus gestiones diplomáticas con Aziru: «(...) observé que temía muchísimo el creciente poderío de los hititas. Me dijo, sin embargo, que los sacerdotes de Marduk habían predicho que el poderío de los hititas duraría un siglo (...). La idea de que esto ocurriría dentro de un centenar de años no me tranquilizaba en absoluto (...)" (WALTARI, Sinuhé p. 531). Realmente el poderío hitita duró hasta inicios del s. XII a.C. (con el fin del período del Bronce). Por otro lado, la alianza entre ambos Estados, Babilonia y Egipto, se hace necesaria, incluyendo un nuevo matrimonio interdinástico, que sorprende a los enviados de Aziru y de Hatti en El-Amarna: «Babilonia buscaba una doble alianza con Egipto por miedo a los hititas» (WALTARI, Sinuhé p. 533). «Los rostros desconcertados del embajador de Aziru y del delegado de los khatti hubieran bastado para disipar nuestros temores y reforzar nuestro júbilo» (WALTARI, Sinuhé p. 534.)

92 WALTARI, Sinuhé, pp. 562 ss.

93 Sobre estos cuatro faraones, de reinados no demasiado prolongados (salvo Horemheb), de dudosos parentescos y orígenes, y poco conocidos en muchos casos, vid. PÉREZ LARGACHA, A., «Los últimos años del período amarniense», Espacio, tiempo y forma. Serie II, Historia Antigua 7 (1994), pp. 41 ss. (previamente, cf. FAIRMAN, H., "Tutankhamun and the End of the 18th Dynasty», Antiquity 46 [1972], pp. 15 ss.; y KRAUSS, R., Das Ende der Amarnazeit. Beiträge zur Geschichte und Chronologie des Neuen Reiches, Hildesheim 1978).

${ }_{94}$ Con la adopción del dios Atón (el «disco solar») y la supresión de cultos como el del poderoso Amón, entre otros, PÉREZ LARGACHA, A., «Atón, Ajenatón y Nefertití. Algunas reflexiones sobre la religión Amarniense», 'llu 0 (1995), pp. 187 ss. 
mación sobre la personalidad de estos faraones que no se corresponde con la realidad de los datos que se tiene de ellos. Lo que sí parece más adecuado es lo mucho tenía que recuperar el Estado egipcio dentro y fuera de sus fronteras, y es aquí donde las campañas en la región sirio-palestina tuvieron una reactivación a manos del belicoso general Horemheb, en particular bajo Tutankhamón y Ay.

Realmente, Siria septentrional se había convertido para los hititas en un espacio de expansión natural y de atracción permanente. El renio de Hatti se enfrentó tanto a otras potencias rivales (primero Mitanni, Egipto y posteriormente Asiria) como a los pequeños Estados sirios que oscilaron en su fidelidad hacia los grandes estados que les rodeaban. Así, en el s.XIV a.C., el gran Suppiluliuma consiguió con las campañas sirio-hurritas y su destacada labor diplomática conquistar y desmantelar el sistema geopolítico establecido en la región por egipcios y hurritas que hasta entonces se habían repartido el dominio ${ }^{95}$.

Frente a lo que pudo ocurrir en realidad bajo el reinado de Suppiluliuma, la relación de los acontecimientos expuestos por Waltari se puede sintetizar en: a) los hititas con ayuda de sus aliados han conseguido llegar a los territorios propiamente egipcios $^{96}$; b) Horemheb, se ensalza y se erige como el único salvador, paralelamente al largo proceso que lleva al fin del período amarniense y a que se sucedan

95 Entre otros, KITCHEN, K. A., op. cit., 1962 (cf. HOUWINK TEN CATE, Ph. H. J., BiOr 20, 1963, p. 270 ss.); SPALINGER, A. J., «Egyptian-Hittite Relations at the Close of the Amarna Period and Some Notes on Hittite Military Strategy in North Syria», Bulletin of the Egyptological Seminar 1, 1979, pp. 55 ss.; MURNANE, W. J., The Road to Kadesh, Chicago 1990, pp. 1 ss; FREU, J., op. cit., 1992, pp. 39 ss.; GONZÁLEZ SALAZAR, J. M., Suppiluliuma, pp. 63 ss. y 95 ss.

96 «A principios de invierno se divulgó la noticia de que Aziru había abierto la mayoría de las ciudades sirias a los hititas y que los carros hititas habían atravesado el desierto de Sinaí y atacado Tanis, devastando toda la región» (WALTARI, Sinuhé, pp. 566).Con los babilonios y Aziru como aliados de Hatti, y datos de cómo atraviesan el desierto con un buen abastecimiento de agua, Horemheb intenta por todos los medios que el faraón se involucre, siendo él, como general en jefe, el salvador: «-Burraburiash ha comprado la paz a los hititas y Aziru ha cedido a su presión y se ha aliado con ellos. El número de soldados hititas en Siria es como las arenas del mar y sus carros son numerosos como las estrellas en el cielo y es el fin de Egipto, porque en su malicia han puesto jarras de agua en el desierto en vista de que no disponen de flota. En el desierto disponen de una cantidad de agua inmensa, de manera que en la primavera un ejército podrá atravesar el desierto sin morir de sed (...). En su impaciencia, los carros de Aziru y los hititas han hecho incursiones hasta Tanis y en territorio egipcio, violando así la paz. Cierto es que estas incursiones son poco graves, pero he hecho propagar por el pueblo el rumor de destrucciones terribles y crueldades hititas, de manera que el pueblo está dispuesto para la guerra (...) tu poderío será salvado. Yo lo salvaré y aseguraré a Egipto un triunfo y batiré a los hititas y reconquistaré Siria. Pero necesito para esto todos los recursos de Egipto. ¡Nada de Atón ni Amón! En la guerra el pueblo olvidará sus males y su cólera se descargará en el exterior, y una guerra victoriosa consolidará tu trono. Te prometo una guerra victoriosa, porque soy Horemheb, Hijo del Halcón, y he sido creado para realizar grandes hazañas y mi hora ha sonado al fin» (WALTARI, Sinuhé, p. 567). Ante las peticiones económicas de Horemheb a los ricos egipcios: «los ricos se arrojaron al suelo a sus pies lamentándose y golpearon la tierra con la frente y gritaron que preferían rendirse a los hititas. Fingiendo sorpresa, Horemheb les dijo: -Si es así, me conformaré con vuestros deseos y me parece que mis soldados, que se juegan la piel y la vida, se irritarán al saber que no queréis consentir en ningún sacrificio para la guerra. Creo que no tendrán inconveniente en ataros con cuerdas y embarcaros para entregaros a los hititas como deseáis. Yo lo lamentaré mucho y verdaderamente no sé qué provecho obtendréis de vuestras fortunas abandonadas, que confiscaré, puesto que estaréis con los hititas dando vueltas a la noria con los ojos arrancados (...). Ante estas palabras los ricos gritaron de terror y le besaron las rodillas y aceptaron todas sus proposiciones, si bien maldiciéndolo en su fuero interno» (WALTARI, Sinuhé, p. 612). 
Tradiciones literarias y tradiciones históricas en Sinuhé, el egipcio de Waltari...

en el trono Smenkhkare y Tutankhamón ${ }^{97}$; c) Horemheb se lanza a una campaña asiática acompañado de Sinuhé, que viene a actuar como cronista98; d) se produce una victoria in extremis del ejército egipcio que, si bien con menos efectivos, capacidad militar táctica y experiencia que las tropas hititas, derrocha astucia y valentía insufladas por su general Horemheb ${ }^{99}$; e) aunque este conflicto hitito-egipcio

97 WALTARI, Sinuhé p. 568 ss. Horemheb en un largo discurso apela abiertamente, haciendo uso de una gran manipulación del lenguaje, a la guerra santa con el apoyo de todos, como ejemplo: «一Escúchame, pueblo de Kemi [=Egipto], escúchame, porque soy Horemheb, el Hijo del Halcón, y traigo en mis manos la victoria y el honor inmortal para todos aquellos que quieran seguirme a la guerra santa. En este instante los carros hititas rugen en el desierto del Sinaí y sus vanguardias recorren el Bajo Egipto, y la tierra de Kemi no ha conocido jamás un peligro más temible, porque al lado de los hititas, la antigua dominación de los hiksos era dulce. Los hititas llegan y su número es infinito y su crueldad un horror para todo el pueblo. Destruirán las villas y os reventarán los ojos, violarán a vuestras mujeres y se llevarán a vuestros hijos como esclavos. El trigo no crece donde han pasado sus carros y la tierra se convierte en un desierto cuando han puesto sobre ellos los cascos de sus caballos. Por esto la guerra que les declaro es una guerra santa, porque es una guerra para vuestras vidas y los dioses del país de Kemi, y si todo va bien, reconquistaremos la Siria, y el país de Kemi renacerá y cada cual tendrá la medida llena. Hace ya demasiado tiempo que se ha burlado de nuestra debilidad» (WALTARI, Sinuhé, pp. 605 ss.). Los propios soldados establecen un símil de Horemheb con su principal símbolo el halcón: «-No hay nada que temer, porque el brazo potente de Horemheb nos protege. No hay nada que temer, porque se arroja como un halcón sobre los hititas y les vacía los ojos y los ciega» (WALTARI, Sinuhé p. 620).

98 La única fortaleza que sitiada que se defiende es la de Ghaza (un lugar estratégico entre los territorios sirio-palestinos y Egipto), con guarnición egipcia (WALTARI, Sinuhé p. 615 s.), sin embargo comienzan las primeras escaramuzas con victoria sobre los hititas en el delta del Nilo y de ahí hacia el Sinaí, sin que Horemheb tenga una estrategia predeterminada: «Horemheb conquistó así todos los depósitos de agua del desierto del Sinaí sorprendiendo a los hititas, que no podían imaginarse que se atrevería a lanzarse a través del desierto (...) su ejército no estaba todavía unido, había tenido que diseminarse por las ciudades de Siria esperando la caída de Ghaza (...) los hititas eran muy minuciosos en sus preparativos militares y no pasaban a la ofensiva hasta que estaban seguros de su superioridad (...). Por esto quedaron sorprendidos ante la brusca ofensiva de Horemheb, porque hasta entonces nadie había osado atacarlos y pensaban que los egipcios no tenían suficiente número de carros para una ofensiva de esta importancia» (WALTARI, Sinuhé, p. 616). En definitiva: «Atravesando el desierto a marchas forzadas, bajo el polvo y el calor (...) es comprensible que tenga que narrar aquí los horrores de la guerra y no la embriaguez de las batallas. (...) El desierto es frío por la noche, después del calor sofocante del día, y los soldados que han caminado descalzos durante semanas enteras sobre la arena ardiente, por entre las plantas espinosas, gimen y gritan durmiendo, lo cual ha creado, probablemente, la leyenda de que el desierto está poblado de malos espíritus. Antes del alba sonó la trompeta y los soldados reemprendieron su marcha agotadora y muchos se caían de cansancio (...) Cuando llegamos cerca del campamento vimos todo el horizonte cubierto de nubes de polvo, porque los hititas llegaban por fin para reconquistar sus depósitos de agua" (WALTARI, Sinuhé, pp. 619 ss.). La batalla tuvo lugar durante tres días (WALTARI, Sinuhé, pp. 626 ss.) y el enfrentamiento, a pesar de las bajas, fue favorable para Horemheb: «A la caída de la tarde el viento sopló del desierto y barrió las nubes de polvo y descubrió el campo de batalla y la terrible derrota de los hititas, que habían perdido la mayoría de sus carros pesados, y otro gran número de carros había caído en manos de Horemheb con sus caballos. Pero los vencedores, agotados y excitados por el ardor del combate, por las heridas y el olor de sangre, se asustaron al ver sus propias pérdidas, porque los cadáveres de los egipcios eran mucho más numerosos que los de los hititas» (WALTARI, Sinuhé, pp. 631 ss.).

99 Una vez que los ejércitos toman contacto, y previamente al enfrentamiento, los egipcios preparan trampas en el campo de batalla (el «Llano de las osamentas») contra los carros hititas (ligeros y pesados, siempre objetivo de los egipcios) que son muchísimo más numerosos. Horemheb arenga a sus tropas con frases del tipo: «(...) los carros hititas tienen hoy que forzar el paso o retirarse a Siria a esperar haber renovado sus depósitos. Si fuesen inteligentes, renunciarían a la batalla y se retirarían a Siria, pero son ambiciosos (...) sus caballos tropezarán enredándose las patas en nuestras cuerdas y el asalto de sus carros, que es la fuerza de los hititas, será anulado por las trincheras que habéis abierto sin reparar en los esfuerzos. (...) Recordad que los palos que lleváis en la mano son lanzas y no están hechas para rascaros las nalgas, sino para reventar las barrigas de los hititas. $Y$ a los arqueros que se creen muy listos porque tienden el arco y lanzan al aire una flecha, les digo que hay que apuntar a los hititas, y si sois 
no finaliza aquí, el enfrentamiento en el desierto trae la derrota de los todopoderosos carros hititas y es el principio del fin de la posible ocupación permanente de, al menos, el Bajo Egipto ${ }^{100}$. El relato de Sinuhé lo resume todo:

Debo de hablar ahora de la guerra de Siria, pero mi relato será breve porque no entiendo gran cosa en asuntos militares, y todas las batallas se parecen para mí y todas las ciudades incendiadas y las casas saqueadas son semejantes, y las mujeres llorando y los cuerpos descuartizados son idénticos, estén donde estén. Si lo contase todo minuciosamente, mi relato sería muy monótono, porque la guerra de Siria duró tres años y fue una guerra cruel e implacable, porque muchos poblados sirios quedaron despoblados y los árboles eran cortados en los huertos y los pueblos se despoblaban ${ }^{101}$.

Así guerreaba Horemheb en Siria y yo le seguía para curar a los heridos y me daba cuenta de todo el mal que el hombre puede hacer al hombre. La guerra duró tres años y Horemheb batió a los hititas y las tropas de Aziru en muchas batallas y dos veces los carros hititas sorprendieron sus tropas y le causaron grandes daños (...) las ciudades de Siria eran saqueadas y la gente se ocultaba en las grutas de las montañas. Provincias enteras fueron devastadas y las tropas destruían los cultivos y cortaban los árboles frutales (...).

Horemheb combatió tres años en Siria y durante estos años yo envejecí más que durante los precedentes, y perdí mis cabellos, y mi espalda se encorvó, y mi rostro se arrugó como un fruto podrido. Me convertí en hombre de mal genio y malhumorado y hablaba con rudeza a los enfermos como hace todo médico al envejecer.

El tercer año se declaró la peste en Siria, porque la peste sigue siempre los rastros de la guerra y nace en cuanto un número suficiente de cadáveres se pudre en un mismo lugar. En realidad toda Siria no era ya más que una fosa pestilente, y tribus enteras fueron exterminadas $(\ldots)^{102}$.

La paz no era más que cuestión de tiempo, y con ella Aziru parece ser el «cabeza de turco», aunque sin ningún arrepentimiento por lo que ha provocado:

Con la crecida, la peste desapareció de Egipto aquel mismo año, y el invierno la suprimió en Siria, de manera que Horemheb pudo reunir a sus tropas y reanudar las hostilidades. En primavera, llegó a través de las montañas a la llanura vecina de Megiddo y batió a los hititas en una gran batalla, después de la cual pidieron la paz porque, viendo los triunfos de Horemheb, el rey Burraburiash había recobrado la confianza, recordando su alianza con Egipto. Se mostró arrogante con los hititas, e invadiendo el antiguo país de Mitanni, arrojó a los hititas de sus pastos de Naha-

verdaderos soldados les sacaréis los ojos. Pero es inútil daros estas instrucciones, de manera que contentaos con apuntar a los caballos que son un blanco suficientemente grande para vosotros" (WALTARI, Sinuhé, pp. 623 ss.).

100 Muchos de los pequeños Estados sirios vuelven al redil egipcio: «su derrota [de los hititas] había suscitado una gran inquietud en Siria y numerosas Ciudades se levantaron contra Aziru y le cerraron las puertas, porque estaban cansados de la ambición de Aziru y de la rapacidad de los hititas y pensaban en granjearse la amistad de Egipto, cuya pronta victoria se daba por descontada. En efecto, las ciudades de Siria han estado siempre desunidas y los emisarios de Horemheb sembraban la discordia y propalaban rumores exagerados y espantosos sobre la derrota de los hititas en el desierto» (WALTARI, Sinuhé, pp. 634). Horemheb puede ahora acudir en ayuda de Ghaza que será liberada (WALTARI, Sinuhé, pp. 636 ss.).

101 WALTARI, Sinuhé, pp. 635 ss.

102 WALTARI, Sinuhé, pp. 653 ss. 
Tradiciones literarias y tradiciones históricas en Sinuhé, el egipcio de Waltari...

rani. Viendo que no podían conseguir ya nada de una Siria devastada, los hititas ofrecieron la paz, porque eran soldados prudentes y hombres económicos, y no querían arriesgar por una simple cuestión de honor los carros de guerra que necesitaban para dar una merecida corrección a los babilonios.

Horemheb fue muy feliz al firmar la paz, porque sus tropas se habían agotado y la guerra había arruinado a Egipto, y quería emprender la reconstrucción de Siria a fin de reanimar el comercio en provecho de Egipto.

(...) los hititas aprisionaron a Aziru y su familia en Megiddo y se apoderaron de los enormes tesoros que había acumulados y entregaron a Horemheb a Aziru, su mujer y sus dos hijos, cargados de cadenas. Habiendo dado así un rehén a los egipcios, que comenzaron a saquear Megiddo y a empujar hacia el Norte, fuera de los terrenos que debían abandonar, todos los rebaños y ganados del país de Amurrú. Horemheb no se lo impidió, sino que hizo sonar las trompetas para anunciar el fin de la guerra y ofreció banquetes a los jefes hititas y a los príncipes, bebiendo todas las noches con ellos y jactándose de sus hazañas. Y al día siguiente haría ejecutar a Aziru y su familia delante de las tropas reunidas y los jefes hititas, para señalar la paz eterna que reinaría en adelante entre Egipto y el país de Khatti ${ }^{103}$.

En definitiva, todos estos episodios, que no son definitivos ${ }^{104}$ y vienen a durar unos tres años, son la «guerra santa» de liberación encabezada por Horemheb ${ }^{105}$.

2.5. El último punto destacado de Sinuhé sobre los hititas es la conocida petición de un hijo por parte de la princesa egipcia Baketamón (hermana de Akhenatón) a Suppiluliuma, en un intento de unión matrimonial interdinástica. Waltari nos lo presenta como una especie de complot de Baketamón y de la reina viuda Nefertiti, a la muerte de Tutankhamón, con apoyo de los propios hititas para frustrar los planes que Ay y Horemheb tienen sobre la sucesión. Éstos descubren horrorizados el plan que se estaba urdiendo contra ellos:

Vio [=Horemheb] por azar a un emisario hitita que penetraba en las habitaciones de la princesa y se preguntó por qué Baketamon recibía un hitita y estaba tanto rato

103 WALTARI, Sinuhé, p. 655. Como dice Sinuhé de manera contundente en su última visita a Aziru: «-Aziru, rey de Amurrú, recuerda que toda la Siria no es más que una fosa llena de cadáveres podridos a causa de tu ambición. Innumerables son los que han muerto por tu causa. Por esto es justo que mueras mañana, puesto que estás vencido, y es justo también que tu familia perezca contigo" (WALTARI, Sinuhé, p. 658).

104 «Así murió mi amigo Aziru sin tratar de corromper la muerte, y Horemheb hizo la paz con los hititas, sabiendo, sin embargo, tan bien como ellos que todo no era más que una tregua, porque Sidón, Simyra, Biblos y Kadesh seguían en poder de los hititas, que hicieron de esta última ciudad una plaza fuerte y una base en la Siria del Norte. Pero los dos bandos estaban cansados de la guerra y Horemheb era feliz de haber llegado a una paz con ellos, porque tenía que velar por sus intereses en Tebas, y tenía que pacificar también el país de Kush y los negros que se habían embriagado con su libertad y se negaban a pagar su tributo a Egipto. Durante estos años el faraón Tutankhamon reinaba sobre Egipto (...)» (WALTARI, Sinuhé, pp. 665 ss.).

105 WALTARI, Sinuhé, pp. 611 ss. En cuanto a Horemheb y la(s) campaña(s) hacia las regiones sirio-palestinas, REDFORD, D., «New Light on the Asiatic Campaigning of Horemheb», BASOR 211 (1973), pp. 36 ss. (cf. DEL MONTE, G., «Muršili II e l'Egitto», en Fs. E. Bresciani, 1985, pp. 161 ss., Mursili II, hijo y segundo sucesor de Suppiluliuma, y Horemheb como faraón; MURNANE, W. J., op. cit., 1990, pp. 30 ss.). En general, sobre este faraón, von BECKERATH, J., «Haremheb», Lexikon der Ägyptologie II (1995), pp. 962 ss.; DELLA MONICA, M., Horemheb, Général Pharaon, Paris, 2001; BOOTH, Ch., Horemheb: The Forgotten Pharaoh, Stroud 2009. 
a solas con él. Por esto, por propia iniciativa y sin consultar a nadie, hizo detener al hitita, quien, en su arrogancia, profirió amenazas y habló de una forma como sólo puede hablar una persona muy segura de su poderío.

Entonces Horemheb le contó todo a Ai y penetraron por la fuerza en la habitación de Baketamon, después de haber matado a un esclavo que se oponía, y en la ceniza del brasero encontraron la correspondencia cambiada con los hititas. Después de haber leído estas tablillas de cera se quedaron aterrorizados y pusieron a Nefertiti y Baketamon bajo una estrecha vigilancia ${ }^{106}$.

Sinuhé lee las pruebas que hay sobre la petición de la princesa a Suppiluliuma:

Horemheb sacó entonces las tablillas de arcilla del rey Shubbiluliuma y me las hizo leer, así como la copia de las respuestas de Baketamon. Terminada la lectura, no tuve ya ganas de reír, y el vino perdió su sabor en mi boca, porque he aquí lo que Baketamon había escrito a los hititas:

Soy la hija del faraón y por mis venas corre sangre sagrada y no hay en Egipto ningún hombre digno de mí. Me he enterado de que tienes numerosos hijos. Envía aquí a uno de ellos para que yo pueda romper una jarra con él, y tu hijo reinará a mi lado sobre el país de Kemi.

Esta carta era tan inconcebible que el prudente Shubbiluliuma se había negado al principio a creer en ella y había mandado un emisario secreto para concretar más. Baketamon había confirmado su oferta asegurándole que los nobles egipcios estaban de su parte y que los sacerdotes de Amón estaban también de acuerdo. Convencido por esta carta, el rey se había apresurado a hacer la paz con Horemheb y se disponía a enviar a su hijo Shubbatú a Egipto ${ }^{107}$.

Suppiluliuma manda a su hijo el príncipe Subbatú ${ }^{108}$ hacia Egipto, pero ante la ambición sin escrúpulos de Ay y Horemheb deciden enviar a Sinuhé para que acabe con él. Sinuhé se encuentra con Subbatú a pocas jornadas de Egipto, en pleno desierto ${ }^{109}$. En boca del hitita, mientras confraterniza comiendo con Sinuhé, se observa lo que depararía el futuro con el vínculo entre las dos casas reales:

106 WALTARI, Sinuhé, pp. 673 ss.

107 WALTARI, Sinuhé, pp. 674 ss.

108 Nombre que no aparece en el elenco de los conocidos entre los hititas, LAROCHE, E., Les noms des Hittites, Paris 1966 (cf. LAROCHE, «Les noms des Hitittes: supplement», Hethitica 4 [1981], pp. 3 ss.). En la discusión entre Horemheb y Ay, lo que dice este último es significativo del miedo que tienen a la llegada del príncipe hitita: «No, Horemheb, si Shubbatú llega a Tebas y rompe una jarra con Baketamon, nuestro poderío se derrumbará y no podremos resistir por las armas, porque sería una nueva guerra y Egipto no podría soportarla y sería el fin del mundo» (WALTARI, Sinuhé, p. 675).

109 El príncipe hitita, que acoge en su campamento a Sinuhé como enviado de Egipto y de la princesa Baketamón, y que busca acercarse a las costumbres egipcias será asesinado por envenenamiento con vino (WALTARI, Sinuhé, pp. 675 ss.). A su muerte: «Todos estaban emocionados por mi compasión y mis lágrimas, y consintieron sin inconveniente en darme una tablilla atestiguando que no era en absoluto responsable de la muerte» (WALTARI, Sinuhé, p. 689). Sin embargo, Sinuhé no puede estar contento: "Así fue como salvé verdaderamente a Egipto del yugo hitita y hubiera debido estar contento de mí, pero no lo estaba en absoluto y tenía la impresión de que, doquiera que fuese, la muerte me seguía pisándome los talones» (WALTARI, Sinuhé, p. 689). 
Tradiciones literarias y tradiciones históricas en Sinuhé, el egipcio de Waltari...

Por el Cielo sagrado y la Tierra madre, una vez el país de Khatti y Egipto no formen más que un imperio, ningún Estado podrá resistirnos y someteremos a los cuatro continentes ${ }^{110}$.

Este enigmático acontecimiento, reflejado en la documentación hitita, no presenta, ni desde la Hititología ni desde la Egiptología, un consenso sobre quiénes pudieron ser los verdaderos protagonistas ni qué fue real y qué ficción ${ }^{111}$. El curioso mensaje, narrado como un relato dentro de un texto histórico, es una solicitud de alianza matrimonial impensable para las costumbres egipcias ${ }^{112}$. Así, al fallecer el faraón (Nibhururiya en el texto hitita) ${ }^{113}$, la reina viuda (conocida como Dahamunzu) ruega que se le envíe a un príncipe hitita ${ }^{114}$ porque no tiene descendencia. El éxito en las negociaciones podría haber supuesto un reforzamiento del poder de los hititas en todo el Oriente Próximo. La realización de tal matrimonio interdinástico habría proporcionado a Suppiluliuma todo el protagonismo de la esfera internacional, sin embargo, el suceso no tuvo una culminación feliz.

La narración real en la que se apoyó Waltari, manipulada por la propaganda hitita, se intercala en los anales de Suppiluliuma y se inicia cuando éste asediaba la ciudad hurrita de Karkemis en su campaña final contra Mitanni ${ }^{115}$. Las prolon-

110 WALTARI, Sinuhé p. 685.

111 Waltari es capaz de hablar de esta petición del matrimonio y del subsiguiente asesinato del príncipe hitita (vid. RAJALA, op. cit., 2008, p. 488), teniendo presente que es un hecho que figura en las fuentes hititas. Así, algunos datos de este acontecimiento pudieron llegar a Waltari de alguna manera, ZIMMERN, H. y FRIEDRICH, J., «Der Briefwechsel zwischen Šubbiluliumaš und der Witwe des Bib/phururijaš (d. i. Amenophis IV?)», ZA 35 (1923), pp. 37 ss.; GOETZE, A., «Zum Briefwechsel zwischen Šuppiluliuma und der Witwe des Biphururijas», OLZ27 (1924), pp. 581 ss.; GÜTERBOCK, H. G., DŠ, pp. 94 ss. (sobre el nombre del faraón, Nb-hpr.w-R', y las referencias en el texto, p. 123); FEDERN, W., «Dahamunzu (KBo V 6 III 8)», JCS 14 (1960), p. 33; LIVERANI, M., «Zannanza», SMEA 14 (1971), pp. 161 s.; PINTORE, F., op. cit., 1978, pp. 46 ss. (cf. ZACCAGNINI, C., Fs. E. Bresciani, 1985, p. 595); SCHULMAN, A. R., «Ankhesenam n, Nofretity and the Amka Affair», JARCE 15 (1978), pp. 43 ss.; EDEL, E. «Ein neugefundenen Brieffragment der Witwe des Tutanchamun aus Boghazköy», Orientalistika 2 (1978), pp. 33 ss.; WILHELM, G. y BOESE, J., «Absolute Chronologie und die hethitische Geschichte des 15. und 14. Jahrhunterts v. Chr», en High, Middle or Low? Acts of an International Colloquium on Absolute Chronology Held at the University of Gothenburg 20th-22nd August 1987. Gothenburg 1987, pp. 82 ss.; HAGENBUCHNER, A., Die Korrespondenz der Hethiter, II, Heidelberg 1989, pp. 304 ss.; MURNANE, W. J., op. cit., 1990, pp. 23 ss.; BRYCE, T. R., «The Death of Niphururiya and its Aftermath», JEA 76 (1990), pp. 97 ss.; FREU, J., op. cit., 1992, pp. 81 ss. y 91 ss. (cf. DEL MONTE, G. L'Annalistica ittita, Brescia 1993, pp. 42 ss.); MILLER, J. R., «Amarna Age Chronology and the Identity of Nibhururiya in the Light of a Newly Reconstructed Hittite Text», AoF 34 (2007), pp. 252 ss.; FREU, Suppipluliuma et la veuve du pharaon. Histoire d'un mariage manque. Essai sur les relations egypto-hittites, Paris 2005; y GONZALEZ SALAZAR, J. M., Suppiuliuma, pp. 75 ss.

112 Vid. supra.

113 Sin una precisa identificación se especula entre el propio Akhenatón (cuyo nombre de trono es $N f r-h p r w-R$ ', Naph[urr]uriya) y sus sucesores y miembros de la familia real: Smenkhkare ('nh-hprw- $R$ ', Ankhkheperure) o Tutankhamón (Nb-hprw-R', Nibkheprure), vid. referencias previas.

114 El nombre del príncipe que aparece en el texto hitita como hijo de Suppiluliuma y candidato al matrimonio es Zannanza, sin embargo, no hay que descartar que los nombres de los potenciales cónyuges sean ficticios. Así, Dahamunzu y Zannanza, serían una trascripción en cuneiforme de «Mujer del faraón» e «Hijo del rey», respectivamente, FEDERN, W., op. cit., 1960, p. 33; LIVERANI, M., op. cit., 1971, pp. 161 ss.; SCHULMAN, A. R., op. cit., 1978, pp. 43 ss; y KITCHEN, K. A., «The Basics of Egyptian Chronology in Relation to the Bronze Age», en High, Middle or Low?, 1987, p. 157. Si se acepta que fue Tutankhamón el faraón fallecido, la viuda (Dahamunzu) acaso haga referencia a Ankhesenamón, la joven hija de Akhenatón y Nefertiti.

115 Allí le llega la petición: «Y por añadidura, para colmo, dado que su señor Nibhururiya había muerto, la reina de Egipto, que era Dahamunzu, envió un mensajero a mi padre (Suppiluliuma), y del siguiente 
gadas negociaciones para el matrimonio entre ambas casas reales comienzan mientras el rey hitita continuaba sometiendo los últimos reductos hurritas en Siria septentrional ${ }^{116}$. Suppiluliuma no desaprovechó la oportunidad y envía a su hijo, a pesar de la desconfianza que subyace durante el proceso ${ }^{117}$. Sin embargo, las intrigas en la corte egipcia influyeron en el asesinato del príncipe hitita cuando fue enviado a Egipto ${ }^{118}$. Un hecho luctuoso que, acaso, fue una de las consecuencias de la intensificación de la guerra y la agudización de la enemistad entre ambos Estados ${ }^{119}$.

modo le escribió: «Mi marido ha muerto y no tengo un hijo mío, pero de ti se dice que tienes muchos hijos. Si tú me dieras un hijo tuyo, se convertiría en mi marido. iYo nunca escogeré un siervo mío para hacerlo mi marido! ¡Tengo miedo [...]!». Cuando mi padre escuchó esto, llamó a consulta a los Grandes (del reino, diciendo): « ¿Una cosa de tal género jamás me había sucedido en toda mi vida!». Entonces mi padre fue y envió a Hattusaziti, el chambelán, al país de Egipto (con esta orden): “ Ve y tráeme tú de nuevo palabras fiables! Quizás quieran engañarme, y quizás tienen un hijo de su señor. ¡Tráeme tú nuevamente palabras fiables!». Y mientras Hattusaziti volvía del país de Egipto, mi padre venció finalmente la ciudad de Karkemis". Sobre el fragmento (A iii 5 ss.) de los Anales de Suppiluliuma (CTH 40), vid. GÜTERBOCK, H. G., DŠ, pp. 94 ss., fragmento 28 (cf. CANCIK, H., Grundzüge der hethitischen und alttestamentlischen Geschichtsschreibung, Wiesbaden 1976, pp. 163 ss.).

116 «Cuando llegó la primavera, Hattusaziti volvió del país de Egipto, y el mensajero de Egipto, el señor Hani, vino con él. Puesto que mi padre había enviado a Hattusaziti al país de Egipto, y del siguiente modo le había mandado: "Quizás tienen un hijo de su señor, a mí quieran engañarme, y no desean a mi hijo para el reino". La reina de Egipto le respondió mediante una tablilla a mi padre del siguiente modo: “¿Por qué dijiste así?: «¡A mí quieren engañarme!». Si yo tuviera un hijo mío, ¿habría yo escrito a un país extranjero sobre mi humillación y la de mi país? ¡Tú no has confiado en mí, e incluso me has hablado así! El que fue mi esposo se ha muerto, y un hijo mío no tengo. ¡Nunca tomaré un siervo mío y lo haré mi esposo! ¡No he escrito a ningún otro país, te he escrito a ti! Se dice que tienes muchos hijos. ¡Dame uno de tus hijos! ¡Él (será) mi esposo y rey en el país de Egipto!». Dado que mi padre era generoso, fue complaciente con el asunto de la mujer y tomó en mano (el asunto) del hijo" (CTH 40, $\mathrm{E}_{3}$ iii 24A iii 44 ss., $D \check{S}$, pp. 96 ss.).

117 Iniciando el diálogo con Hani los enfrentamientos entre hititas y egipcios continúan sobre las negociaciones matrimoniales: " $Y$ cuando (las huestes hititas) atacaron el valle del Amka [=Valle de la Beqa], iquizás os asustasteis! y(, por tanto,) deseáis de mí insistentemente un hijo mío [...]. De alguna manera, él se convertirá en un rehén y no lo haréis rey (de Egipto)». Hani (respondió) así a mi padre: « ¿Mi señor, esta es la humillación de nuestra reina y de nuestro país! ¿Si nosotros hubiésemos tenido algún hijo del rey, habríamos ido a un país extranjero y deseado insistentemente un señor para nosotros? Nibhururiya, que fue nuestro señor, murió, pero no tuvo un hijo. La esposa de nuestro señor está sola. Por esto, estamos buscando insistentemente un hijo de nuestro señor (Suppiluliuma) para el reino en el país de Egipto, y, por consiguiente, lo estamos buscando insistentemente como su marido para la esposa, nuestra señora. Además, no fuimos a ningún otro país, i(sólo) aquí vinimos! ¡Nuestro señor, danos a un hijo tuyo!». Entonces mi padre tomó en mano (el asunto) del hijo para ellos» (CTH 40, $\mathrm{E}_{3}$ iv 8 ss., $D S ̌$, pp. 97 ss.).

118 «Cuando trajeron esta tablilla, del siguiente modo hablaron: «Los egipcios han matado a Zannanza y trajeron la noticia: « ¿Zannanza ha muerto!». Cuando mi padre (Suppiluliuma) recibió la noticia del asesinato de Zannanza, comenzó a lamentarse por Zannanza, y a los dioses [...] él habló del siguiente modo: «iOh dioses! Yo no hice ningún mal, sin embargo los egipcios me hicieron eso y me atacaron la frontera de mi país”» (DŠ, p. 107 ss., Fragmento 31, KUB XIX 4, líns.5 ss.). Hay algunos otros textos hititas como la carta KUB XIX 20 (CTH 154) de Suppiluliuma posiblemente al faraón Ay (?), escrita hasta cierto punto en términos hostiles sobre la muerte de su hijo que se relacionarían con este funesto acontecimiento y que podría hacernos pensar en que el faraón muerto citado en el texto (Nibhururiya) era Tutankhamón. Sobre esta documentación epistolar, MURNANE, W. J., op. cit., 1990, pp. 25 ss. (cf. HAGENBUCHNER, A., Korrespond.II, pp. 304 ss. y 437 s., no 208 y 327; y van den HOUT, Th., «Der Falke und das Kücken: der neue Pharao und der hethitische Prinz? », ZA 84, 1994, pp. 60 ss.).

119 Sobre la guerra hitito-egipcia de Suppiluliuma, GONZALEZ SALAZAR, J. M., Suppiuliuma, pp. 80 ss. 
Tradiciones literarias y tradiciones históricas en Sinuhé, el egipcio de Waltari...

2.6. Algunas otras referencias de Waltari a los hititas (reinados de Ay y Horemheb) ${ }^{120}$, muestran que el conflicto sigue latente entre Hatti y Egipto, y así continuará bastantes décadas más, hasta el enfrentamiento en las cercanías de la localidad de Kadesh, durante los reinados del hitita Muwatalli (II) y del egipcio Ramsés II (primer cuarto del s. XIII a.C.).

3. En definitiva, Waltari, el hombre que surgió del frío norte, nos proporciona una cálida y cercana visión de los avatares del reino del valle del Nilo, junto a otros pueblos que habitaban en el Mediterráneo oriental, durante una particular fracción de tiempo de la milenaria historia antigua del Oriente Próximo. Asimismo, los hititas, personajes colaterales desde la visión etnocéntrica egipcia se convierten en uno de los elementos claves de la trama urdida por Waltari. Son un punto de referencia en su posible pretensión de reflejar, con el uso de un lejano mundo antiguo, lo que para él eran los acontecimientos contemporáneos que le habían tocado vivir, en este caso la II Guerra Mundial que no había apagado todavía los últimos rescoldos en el momento de la publicación de Sinuhé.

Waltari sabe de lo que escribe, lo formula de manera elegante y clara, pero lo adapta a su trama argumental y a la psicología de sus personajes, reales y ficti$\operatorname{cios}^{121}$. Sin embargo, a pesar de la muy documentada narración de Waltari y de que muchas de las cosas tal como las cuenta pudieran haber ocurrido ${ }^{122}$, estamos ante una bella recreación histórica. Como algunos afirman, con buen criterio, en relación con las novelas y el cine histórico: «Son éstas, sin duda, extraordinarias creaciones literarias y cinematográficas basadas en la Historia, pero no son la Historia en sí misma»123.

120 Una vez consagrado Ay, el propio Horemheb sabe que no todo ha terminado en cuanto a los conflictos en el exterior y sobre su futura posición: «(...) Horemheb sabía lo que hacía, porque la copa de los sufrimientos no estaba vacía aún. En efecto, noticias alarmantes llegaban del país de Kush, donde habría que guerrear con los negros, y después habría todavía que volver a pelear con los hititas a causa de Siria. Por esto Horemheb deseaba que el pueblo acusase a Ai de todos los sufrimientos debidos a la guerra, para que después lo saludara a él como vencedor que trae de nuevo la paz y la prosperidad» (WALTARI, Sinuhé, pp. 691 ss.). Horemheb tiene que seguir combatiendo en Siria y el Líbano (Kadesh, Biblos, Sidón, Simyra) para restaurar el poder egipcio (WALTARI, Sinuhé, pp. 696 ss.). Asimismo, Horemheb acusa a Sinuhé de hablar mal de él comparando, entre otras cosas, su régimen con el hitita: «-Sinuhé, te he hecho avisar ya muchas veces, pero no haces caso de mis advertencias (...) has osado decir que mi régimen no difiere del de los hititas y una serie de estupideces más (...)» (WALTARI, Sinuhé p. 720), por lo que el faraón dicta sentencia: «-Está decidido; te destierro para siempre y cuando mueras tu cuerpo no podrá ser enterrado en Egipto (...)» (WALTARI, Sinuhé, p. 722). Y es desde su destierro donde ha escrito sus vivencias.

121 En realidad, en la obra de Sinuhé se habla con cierto sentido de distintos temas: medicina, arte y arqueología, $\mathrm{h}^{\mathrm{a}}$ militar, criminología, economía, etc., signo del sólido conocimiento que de la mayoría de las materias que tocaba tenía Waltari (RAJALA, op. cit., 2008, p. 491).

122 RAJALA, op. cit., 2008, pp. 489 ss.

${ }^{123}$ FERNÁNDEZ JURADO, J., «Historia o ficción: de lo que fue a lo que contamos», en III Congreso Español de Antiguo Oriente Próximo (Huelva, 30 de Septiembre al 3 de Octubre de 2003), Huelva Arqueológica 19, Huelva 2004, p. 16. 
